\title{
CALIFORnia Constitutionalism: TRUST In GOVERNMENT AND DIRECT DEMOCRACY
}

\author{
Stephen M. Griffin
}

For anyone who regards U.S. constitutionalism as synonymous with the federal Constitution, the kind of constitutionalism practiced in California can be disorienting. In California and other states, a constitutional and legislative process driven by popular vote runs parallel to the familiar three branches of government. In this Article, I provide a new perspective on the origins and persistence of "California constitutionalism," a kind of constitutional order in which the mechanisms of direct democracy-the initiative, referendum, and recall-are employed to supplement representative democratic institutions. ${ }^{1}$ In California, the initiative and referendum are not merely extra avenues to put legislation on the books. They are crucially important constitutional processes. Through these processes, California voters have repeatedly reshaped their constitutional order and affected the national political agenda. ${ }^{2}$

In contemporary times, direct democracy has been consistently controversial since California voters adopted tax-cutting Proposition 13 in 1978. ${ }^{3}$ The last round of public debate occurred relatively re-

* Rutledge C. Clement, Jr. Professor in Constitutional Law, Tulane Law School. ㄷ 2008 Stephen M. Griffin. E-mail address: sgriffin@tulane.edu. I am grateful to Ethan Leib for making comments on an earlier draft.

1 For recent studies of direct democracy, especially the initiative, see JOHN M. ALLSWANG, THE INITIATIVE AND REFERENDUM In CALIFORNIA, 1898-1998 (2000); SHAUN BOWLER \& Todd Donovan, Demanding Choices: Opinion, Voting, and Direct Democracy (1998); Citizens as Legislators: Direct Democracy in the United States (Shaun Bowler et al. eds., 1998) [hereinafter CitizENS AS LEgISLATORS]; ElisABETH R. GERBER, The Populist Paradox: InTERest Group Influence and the Promise of Direct Legislation (1999); John G. Matsusaka, For the MANY OR the Few: The Initiative, Public Policy, AND American Democracy (2004); Elizabeth Garrett, Hybrid Democracy, 73 GeO. WASH. L. REv. 1096 (2005); Elizabeth Garrett \& Mathew D. McCubbins, The Dual Path Initiative Framework, 80 S. CAL. L. REV. 299 (2007).

2 See, e.g., David S. Broder, Democracy Derailed: Initiative Campaigns and the Power OF MONEY 51-52 (2000) (highlighting the national influence of Proposition 13).

3 See Thomas Goebel, A Government by the People: Direct Democracy in America, 1890-1940, at 189 (2002) ("The pivotal event that demonstrated the potential of the initiative was the property tax revolt in California that culminated in the successful passage of Proposition 13 in 1978."). 
cently, with critics such as David Broder and Peter Schrag decrying what they saw as its adverse consequences for governance. ${ }^{4}$ Whatever the benefits and failings of direct democracy, I suggest insufficient attention has been paid to the historical and institutional question of how we got here in the first place. Sometimes overly hasty criticisms of direct democracy have substituted for a more nuanced analysis of the reality that the United States has multiple constitutional orders or regimes, originating from different periods in its history, operating within its borders.

Coming to terms with the origins of direct democracy depends on understanding constitutional orders as time-bound and contingent. I will argue that direct democracy grew out of the failure of the Framers' eighteenth-century political institutions in the context of late nineteenth-century politics. Direct democracy is thus less a deviation from the Framers' design than a creative supplement forced by fundamentally new circumstances.

My main thesis is that the origins and persistence of direct democracy has to do with the problem of trust in government. ${ }^{5}$ Focusing on the problem of trust establishes a new context for understanding direct democracy. Put simply, citizens are more likely to favor direct democracy when they distrust politicians and how the government works (or appears to work). In such circumstances, the legitimacy of representative government comes into question and the alternative of direct democracy appears reasonable. Once direct democracy is adopted, it is unlikely a purely representative system can be restored without confronting the problem of trust.

In general, trust in government (or rather, the prevalence of distrust) should be regarded as an important constitutional issue. The frequent resort to direct democracy in California and other states should prompt us to rethink whether the system of representative government established by the Founding Generation is adequate to the challenges posed by contemporary politics. Direct democracy is in many respects the paradoxical consequence of the corrosive distrust produced by what scholars might regard as the ordinary and legitimate processes of representative government. Coming to terms

4 See, e.g., BRODER, supra note 2, at 51-52 (decrying the "stunted ... growth" and "administrative nightmare" created by Proposition 13 and the subsequent growth industry devoted to "manipulation of public opinion"); PeTER SCHRAG, PARAdISE LOST: CALIFORNIA's EXPERIENCE, AMERICA'S FUTURE (1998) (depicting California as a state suffering under the burden of previous ballot initiatives).

5 The connection between distrust of government and direct democracy has been noted by its critics. See Broder, supra note 2, at 1-3. 
with direct democracy means appreciating that its flaws, while quite real and substantial, cannot be addressed without acknowledging the serious problems citizens perceive with representative institutions. It is likely that both require fundamental reform.

Why focus on California constitutionalism? California is, of course, an important state $^{6}$ with a distinctive and interesting history that includes frequent recourse to the processes of direct democracy. In addition, California's challenges, such as funding government and coping with racial, ethnic, linguistic, and ideological diversity, tend to be national challenges. ${ }^{7}$ The increased use of direct democracy by the California electorate, especially the initiative, has drawn the attention of scholars, as well as severe criticism from well-informed political observers. ${ }^{8}$ But my reasons for focusing on California go beyond these points. California is worth considering as a "newmodeled" polity of the late nineteenth century. California's present constitution was adopted in 1879 and underwent a significant reordering in the progressive period. As perhaps the best known and most studied example of progressive era constitutionalism, California's experience can be usefully compared with the U.S. Constitution and the constitutional experience of the Founding Generation.

California is such a large and extensive polity ${ }^{9}$ that we can glimpse in it what the U.S. constitutional order might have looked like had it been created through a constitutional convention early in the twentieth century. In some significant ways, California's constitution tracks the structure of the contemporary constitutional order far more closely than does the U.S. Constitution. Most important, the problem of trust in government is a national problem, one not unique to California. Studying California's history can illuminate this ongoing concern with American government.

6 As of the 2000 census, California was the most populous state, having $12.5 \%$ of the population of the United States. It had the fifth largest economy in the world in 2005. KeVIN STARR, CALIFORNIA: A History, at ix (2005).

7 See Mark Baldassare, California in the New Millennium: The Changing Social and POLITICAL LANDSCAPE 17 (2000) (describing California as "a political microcosm for the nation").

8 See BRODER, supra note 2; SCHRAG, supra note 4 (blaming ballot initiatives in large part for California's budgetary woes); see also Richard J. Ellis, Democratic Delusions: The INITIATIVE PROCESS IN AMERICA (2002) (encouraging greater skepticism of ballot initiatives).

$9 \quad$ As California journalist Peter Schrag remarked, "We are not Kansas or Iowa or even Florida. We are a nation state." Peter Schrag, Historian Kevin Starr's Grand California Panorama, SACRAMENTO BeE, Sept. 15, 2004, at B7. 
This Article has three parts. In Part I, I review the history of the origins of direct democracy in California. While the story behind the adoption of the initiative, referendum, and recall is somewhat familiar, important institutional and constitutional questions have often gone unaddressed. In Part II, I first review the contemporary status of direct democracy in California in relation to the problem of trust in government. I then present a detailed explanation of the decline of trust in government in the United States by reviewing the most relevant social science evidence. I argue that the problem of trust in government is a national problem extending back to the 1960s. This suggests that the use of direct democracy will persist until the problems citizens have with representative institutions are acknowledged and addressed. Finally, in Part III, I offer some concluding reflections.

\section{ESTABLISHING DIRECT DEMOCRACY IN CALIFORNIA}

Direct democracy has been part of American government for over a century. ${ }^{10}$ Despite this long history, it remains the subject of a contentious debate. ${ }^{11}$ Indeed, critics often treat it as a newcomer to our constitutional system and tend to concentrate on the question of whether we should be for or against direct democracy. ${ }^{12}$ However, I believe that before we can evaluate any aspect of the American constitutional order, we should have a secure understanding as to why it exists and what purpose it serves.

It is thus appropriate to begin with the original reasons direct democracy was adopted in the early twentieth century. Its adoption can be viewed as something of a puzzle. The conventional wisdom of constitutional scholars is that the system of representative government adopted by the Founding Generation has stood the test of time. If there is a policy that a clear majority of the public favors, their representatives have substantial incentives to give the people what they want. In doing so, they will earn the public's favor and probably be reelected. If this system works to generally implement public opinion, the puzzle is why direct democracy exists at all. If, as many believe, the Framers of the Constitution designed a stable and well-

10 The main wave of state adoptions of the initiative came between 1902 and 1918. JOHN J. DinAN, THE AMERICAN STATE CONSTITUTIONAL TRADITION 94 (2006).

11 ALlswANG, supra note 1 , at 4.

12 See, e.g., Broder, supra note 2, at 1 ("The initiative process, an import now just over one hundred years old, threatens to challenge or even subvert the American system of government in the next few decades."). 
ordered representative government, ${ }^{13}$ how did direct democracy come about?

To answer this question, we should briefly consider the standard story of how direct democracy was adopted in California. ${ }^{14}$ After the "Big Four" of Leland Stanford, Collis P. Huntington, Charles Crocker, and Mark Hopkins ${ }^{15}$ created the Central Pacific and built the transcontinental railroad, its successor, the Southern Pacific, achieved a monopoly over rail transportation in California ${ }^{16}$ and came to dominate its politics. The railroad sought to control the political system in much the same way as it sought to dominate the state's transportation network. It corrupted politicians, political parties, indeed the entire political system. ${ }^{17}$ Certain public-spirited citizens who did not owe their livelihood to the railroad eventually reacted against this corruption and sponsored the Lincoln-Roosevelt League, the political arm of the progressive movement in California. ${ }^{18}$ They contested for power and won control of state government. Led by Governor Hiram Johnson, they enacted various reforms, including the initiative, referendum, and recall in $1911 .^{19}$

The standard story about the origins of direct democracy suggests strongly that the citizens of California had lost confidence in the normal workings of representative democracy. Accounts of the origins of direct democracy often say that its advocates believed their political system was corrupt. ${ }^{20}$ Were they right? If they were, how did this occur and what does it tell us about the system of government bequeathed to California by our constitutional tradition?

13 See, e.g., Mathew D. McCubbins, Putting the State Back into State Government: The Constitution

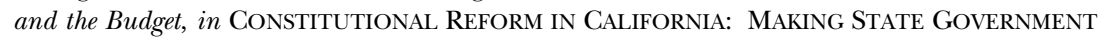
More EFFective AND Responsive 353, 354 (Bruce E. Cain \& Roger G. Noll eds., 1995) [hereinafter CONSTITUTIONAL REFORM IN CALIFORNIA] (blaming reform initiatives starting in the Progressive Era for limiting the effectiveness of California's government).

14 For a useful account, see Karl Manheim \& Edward P. Howard, A Structural Theory of the Initiative Power in California, 31 Loy. L.A. L. Rev. 1165, 1174-90 (1998). See also Nathaniel A. Persily, The Peculiar Geography of Direct Democracy: Why the Initiative, Referendum and Recall Developed in the American West, 2 MICH. L. \& POL'Y REV. 11 (1997) (providing further explanations of the origin of ballot initiatives in Western states).

15 On the "Big Four," see James J. RaWls \& Walton Bean, California: An Interpretive HISTORY 171-73 (2003).

16 Id. at $180-84$.

17 See id. at 231-40.

18 Id. at $260-64$.

19 SCHRAG, supra note 4, at 189-90.

20 E.g., AllswANG, supra note 1, at 5; BRODER, supra note 2, at 26. 
In previous work, I have argued that towards the end of the nineteenth century and the beginning of the twentieth century the United States confronted the need to expand and modernize the national administrative state. ${ }^{21}$ In the early stages of this adjustment, there was a fundamental mismatch between the rudimentary and nonprogrammatic institutions of government at the federal level and the rapidly developing industrial economy, the growth of large-scale business organizations, and an increasingly urbanized and ethnically pluralistic society. ${ }^{22}$ This mismatch strongly influenced the subsequent development of the national state and derived from two gaps between constitutional powers and institutional means. Specifically, the Constitution had created a relatively weak national state with uncertain powers of enforcement and a limited administrative capacity.

Increasingly, Congress had to deal with complex, ongoing regulatory issues that could not be solved through the distribution of benefits. $^{23}$ However, Congress found itself unable to resolve these issues through the legislative process. Political parties and elections could not help because they were not oriented toward national policymaking. There was thus a gap between the public authority the electoral process provided and the kind of public authority the elected branches needed to deal with these new issues. Consequently, there was a move away from vesting public authority in the "democratic party-legislative process." ${ }^{24}$

The establishment of direct democracy in California is a good example of the consequences of the mismatch at the state level between governing institutions and a rapidly modernizing economy. In state constitutions adopted in 1849 and extensively revised in 1879, Californians followed the model of the U.S. Constitution and created a constitutional order with multiple and competing power centers. ${ }^{25}$ However, this pluralistic constitutional arrangement was not supported by a plurality of power centers in the economy and society. In

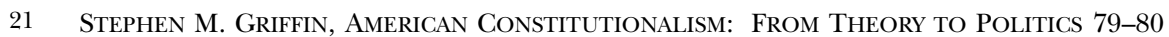
(1996) (citing Stephen SKowronek, BuIlding a NeW AMErican State: The Expansion OF NATIONAL ADMINISTRATIVE CAPACITIES, 1877-1920, at 10-18 (1982)).

22 See generally Alan Dawley, Struggles for Justice: SOCial Responsibility ANd the LiBERAL STATE (1991) (approaching historical conflicts and consensus through an examination of contradictions in social order, structure, and governance).

23 GRIFFIN, supra note 21, at 79 ("The mismatch between private power and public authority led to a kind of breakdown in the constitutional order.").

$24 \quad I d$

25 See CAL. CONST. of 1849, art. III-VI (establishing a government with three separate, coequal branches). The current constitution, adopted in 1879 , maintains the same general structure. See generally CAL. CONST. (maintaining the same structure). 
the nineteenth century, California had only a few power centers, with the Southern Pacific overwhelmingly dominant. ${ }^{26}$ The Southern Pacific sought predictability from the political system in order to recoup its enormous investment in the railroad. It also sought political support for its effort to expand and indeed monopolize California's transportation network. ${ }^{27}$ California thus entered the Union precipitously and without the political maturity that characterized the American colonies in 1776. This observation may strike some as odd, but historians will remind us that the colonies had experienced well over a century of continuous social, economic, political, and legal development on the eve of the Revolutionary War. ${ }^{28}$

California sought admission into the Union only one year after the Gold Rush began and the Treaty of Guadalupe Hidalgo was signed, ending the war with Mexico. ${ }^{29}$ Gold had been discovered at Sutter's Mill just nine days earlier, but the signers were unaware of this event. ${ }^{30}$ The Treaty was ratified in May 1848 and news reached California in August. ${ }^{31}$ Military government continued out of necessity, as Congress could not agree on a territorial government. ${ }^{32}$ As a consequence, California would skip the territorial stage of government entirely. ${ }^{33}$

Prior to the Gold Rush, California's non-Indian population was less than $15,000 .^{34}$ The sudden massive influx caused by gold fever resulted in a population of 223,856 in 1852 . For 1860 the regular census figure was 380,000, and for 1870 more than 560,000, almost all of them men. ${ }^{35}$ These new immigrants did not come to California with the idea of living there permanently. As stated by historians Rawls and Bean:

26 George E. Mowry, The California Progressives 9-22 (1951); Spencer C. Olin, JR., CALIFORNIA's Prodigal SONS: Hiram JOHNSON AND THE Progressives, 1911-1917, at 1-3 (1968); Kevin Starr, Inventing the Dream: California Through the Progressive ERA 199-207 (1985).

27 See William Deverell, Railroad Crossing: CALifornians and the RAILroAd, 18501910, at 27-29 (1994) (detailing the expansionary goals of the "Big Four" railroad companies).

28 For a historical overview, see generally AMERICAN LAW AND THE CONSTITUTIONAL ORDER: Historical Perspectives (Lawrence M. Friedman \& Harry N. Scheiber eds., 1978).

29 RAWLS \& BEAN, supra note 15 , at 95.

30 Id.

$31 \quad I d$. at 117.

$32 \quad I d$.

$33 \quad$ Id. at $117-18$.

$34 \quad I d$. at 111.

$35 I d$ 
The great majority of them came in the hope that they could quickly plunder California of its treasure and return to their homes. . . Most of those who remained in California did so because they failed to accumulate even enough to get them back home. On the whole they were unsuccessful, disillusioned, embittered men.

As historian John Burns remarks, "most gold seekers did not view California as a permanent destination and had little interest in civic affairs." 37

California's first constitutional convention occurred in September 1849. Most of the new constitution was not original, as the delegates followed the examples of Iowa and New York. ${ }^{38}$ The deliberations of the convention showed how difficult it was to maintain the distinction between fundamental principles, which properly belong in a constitution, and legislative matters. ${ }^{39}$ California was then admitted into the Union as part of the Compromise of 1850, in which it was recognized as a free state, but the territories of Utah and New Mexico could be organized without any ban against slavery. ${ }^{40}$

What sort of "state" was it? As Burns states, "It was a lightly occupied, vast area that gained worldwide attention with unprecedented speed.... Public and governmental operations were virtually nonexistent." $^{41}$ The state's political authorities, such as they were, struggled to provide a legal order for a small and transitory population. ${ }^{42}$ Nineteenth-century American government has been described as a state of "courts and parties," ${ }^{43}$ but in California, even these institutions did not exist at this early stage.

One of the most important legacies of the Constitution of 1849 that is relevant to the establishment of direct democracy was its limitation on the number of representatives in both houses of the state legislature. As modified by the 1879 Constitution, the California Assembly may have no more than eighty members and the California

$36 \quad$ Id. at 112.

37 John F. Burns, Taming the Elephant: An Introduction to California's Statehood and Constitutional Era, in TAming the ElePhant: POlitics, Government, and LAW IN Pioneer CALIFORNIA 1, 5 (John F. Burns \& Richard J. Orsi eds., 2003) [hereinafter TAMING THE ELEPHANT]

38 See RAWLS \& BEAN, supra note 15 , at 121.

39 See Gordon Morris Bakken, The Courts, the Legal Profession, and the Development of Law in Early California, in TAMING THE ELEPHANT, supra note 37, at 74, 77 (relating various statements by the delegates concerning both immediate and abstract concerns associated with the formation of a government).

40 RAWLS \& BEAN, supra note 15, at 122-23.

41 Burns, supra note 37 , at 4 .

42 Id. at 4-6.

43 SKOWRONEK, supra note 21, at 24. 
Senate no more than forty. ${ }^{44}$ The consequence today is that the most populous state has enormously large legislative districts, in all likelihood making it more difficult for members of the legislature to represent their constituents effectively. As Peter Schrag noted in 1998, "California's senate districts, each with a population of some 800,000 residents, are larger than its fifty-two congressional districts, making it unlikely that many voters will have any direct contact with their representatives." ${ }^{45}$

Focusing on the adequacy of the system of representation is important, because it is precisely this aspect of the California constitutional order that was targeted as inadequate by the advocates of direct democracy. Californians had acquired a poor opinion of their state legislature by the $1870 \mathrm{~s} .{ }^{46}$ As Judson Grenier notes, "“[c] onflict of interest' was not a commonplace concept ${ }^{\text {"47 }}$ in the legislature. He continues, "That first political factions and then special business interests compromised the integrity of the state legislature was recognized by most nineteenth-century historians and contributed to the public disaffection that led to the second constitutional convention."

The 1879 convention was dominated by a split between the Workingmen's party led by Dennis Kearney and everyone else, both Republicans and Democrats. ${ }^{49}$ In the judgment of historians Rawls and Bean the constitution was not a success: "In place of an imitative, short, and concise document, it produced one that was much more original, extraordinarily long, and extremely detailed. Yet California's second constitutional convention achieved remarkably little net improvement over the first, and virtually every hope of effective reform was ultimately disappointed. ${ }^{, 50}$

Why was the new constitution so much longer than the old? Historian Carl Swisher pointed to the low opinion in which the state legislature was held by delegates. "[T] he delegates looked upon themselves as more truly the representatives of 'the people' than any subsequently chosen legislators, and thought it their duty to include a large amount of important legislation in the constitution, where it

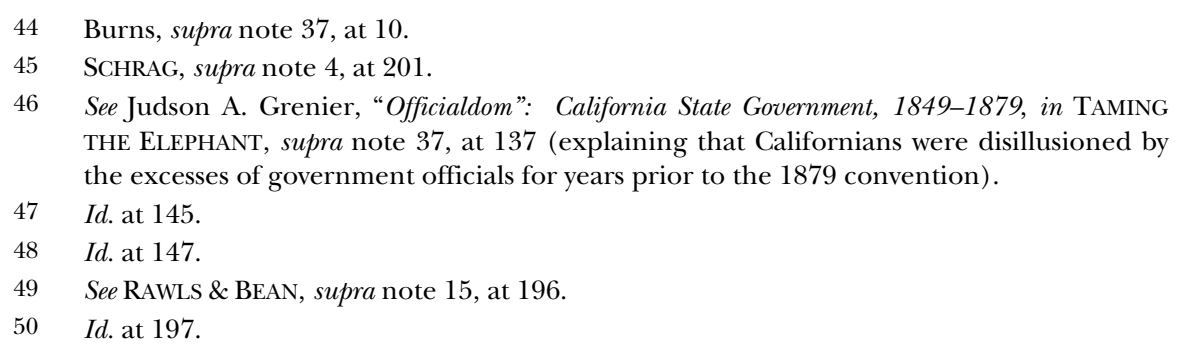


would not be easily subject to change." ${ }^{51}$ The "delegates regarded the legislature as a necessary evil, and an expensive one at that." ${ }^{52} \mathrm{He}$ comments: "If the delegates had come to the convention determined to cinch capital, tax mortgages, and expel the Chinese, they were also determined to put the legislature in its place. Session after session charges of incompetence and corruption had been made against the legislature, not always without reason. ${ }^{, 53}$

At the same time, at least in Swisher's judgment, delegates did not free themselves from the sort of motives that drove state legislators. ${ }^{54}$ The sorry record of the convention indicates that the delegates did not have a good understanding of the problems facing the state or sound ideas about possible solutions. One of the reasons the 1787 Federal Convention was successful was that the delegates had extensive experience with American state and national government. They also had thought about possible solutions and discussed those before the convention began. By contrast, prior to the California convention, "there was little intelligent consideration given to the question of what might be legitimately expected to be achieved by revision of the fundamental law of the state. ${ }^{, 55}$ Swisher concludes with respect to the convention's impact:

The constitution was intended to be a piece of fundamental legislation which would of itself immediately reorganize and redirect the political life of the state. Instead, in the light of a retrospect of fifty years, it seems to have been only one skirmish in a series of battles that have raged during and since the decade of the seventies. ${ }^{56}$

The Constitution of 1879 failed to achieve any of its goals. It did not result in effective railroad regulation, tax relief for farmers, help for workers, or (thankfully) exclusion of the Chinese. ${ }^{57}$ However, it remains California's foundational law. ${ }^{58}$

51 Carl Brent Swisher, Motivation and Political Technique in the California Constitutional Convention, 1878-79, at 65 (Da Capo Press 1969) (1930).

$52 \quad I d$. at 96.

$53 \quad I d$.

54 See id. at 85 ("Throughout the discussion of all the diverse provisions of taxation it was strikingly evident that the delegates were not seeking to discover or to apply any fundamental principles of public finance. They were concerned primarily with shifting from themselves and their constituents as much as possible of the burden of taxation. The motive, throughout, was economic self interest ....").

$55 \quad I d$. at 18.

$56 \quad I d$. at 114.

57 See Burns, supra note 37, at 13 (noting that "the new constitution did little" to advance the drafters' initial interests).

58 See id. at 16 (explaining how, in spite of numerous amendments, the 1879 Constitution affects modern California). 
Most important for our story, the new constitution did not improve the reputation of the state legislature. By the $1880 \mathrm{~s}$, criticism of the legislature for abuse of the patronage system and the use of special legislation that benefited particular lobbyists and businessmen was common. ${ }^{59}$ State legislators were not well paid and this made them easy prey for well financed lobbyists.

Members of the Founding Generation might have been able to diagnose what was wrong with the Californian political system. By traditional republican standards, California lacked the kind of political economy necessary to support representative government. Civic republicans such as Thomas Jefferson believed that good government flowed from the ready availability of land. ${ }^{60}$ Widespread freehold ownership would guarantee the existence of a republican political order. Yet in California, land ownership was concentrated and citizens complained of a land monopoly. ${ }^{61}$ A middle class of yeoman farmers never developed. From an eighteenth century point of view, the prospects were never good that republican government would function as well on the Pacific coast as it did on the Atlantic. ${ }^{62}$

The operations of the Southern Pacific made the attainment of republican government even more difficult. Historian Kevin Starr writes that the railroad "offered the most obvious instance of what was grossly wrong with California: a very few of the super-rich virtually owned the state-its land, its economy, its government-and were running it as a private preserve." ${ }^{33}$ In 1883 , hundreds of letters between Collis Huntington and associate David Colton dating from 1874 to 1878 were made public in the course of a lawsuit. "The bulk of these letters dealt with the delicate matter of bribing Washington

59 See Donald J. PisAni, From the Family Farm to Agribusiness: The Irrigation Crusade IN CALIFORNIA AND THE WEST, 1850-1931, at 21-24 (1984) (listing examples of patronage positions and press denunciations of the patronage system).

60 See Gregory S. Alexander, Commodity \& Propriety: Competing Visions of Property IN AMERICAN LEGAL THOUGHT, 1776-1970, at 30-34 (1997) (describing property rights as a foundational aspect of Jeffersonian civic republicanism); DREW R. MCCOY, THE ELUSIVE RePUblic: Political Economy in JefFersonian America 186 (1980) (listing "an unobstructed access to an ample supply of open land" as central to Jefferson's conception of a sustainable political economy).

61 PISANI, supra note 59, at 11-15; see also OLIN, supra note 26, at 27-28 (illustrating the vehement public outcry over land monopoly).

62 In his important historical study, Thomas Goebel argues that " $\mathrm{t}]$ he vision that inspired many direct democracy reformers was a distinctly economic one, that of a republic of small independent producers freely competing in an unfettered marketplace." GOEBEL, supra note 3 , at 5 .

63 STARR, supra note 26, at 199. 
congressmen and Sacramento legislators to favor pro-railroad legislation." ${ }^{64}$

During the legislative session that began in January 1907, the citizens of the state were informed by the press that "no important action was taken in either house without the sanction of [the] three top members of the Southern Pacific's legislative directorate." ${ }^{, 65}$ Kevin Starr comments, "[t]he last four years of the [Southern Pacific]'s control over California were the most flagrant. Certainly the legislature of 1907 set new records for influence-peddling and outright bribery." ${ }^{, 6}$ The progressive editor of the Fresno Republican concluded that " $[\mathrm{t}]$ he state had lost ... the things for which the Revolutionary and Civil wars were fought. Unless California arose and overthrew corrupt corporation government as Wisconsin had done, then its peoples were not fit for self-government.." ${ }^{, 7}$ California was ready for change. ${ }^{68}$

The elite group of progressives that met after this sorry legislative performance to form the Lincoln-Roosevelt League were in favor of many specific reforms such as "the direct primary, the initiative, referendum, and recall, the regulation of utility rates, conservation of forests, the outlawing of race-track gambling, a workmen's compensation law, woman suffrage, a blue-sky law, and a minimum-wage law for women." ${ }^{69}$ But the first plank in their platform was to emancipate "the Republican Party in California from domination by the Political Bureau of the Southern Pacific Railroad Company." "70 From the perspective of the progressives, the entire political system was the captive of a particularly powerful special interest, and on this point they were indisputably correct.

Californians thus had good reason to believe that something had gone terribly wrong with representative government. But does this indicate a problem with the representative principle itself? Defenders of representative democracy would surely say not. We should keep in mind, however, that the Founding Generation believed that the maintenance of a republican constitutional order rested on a cer-

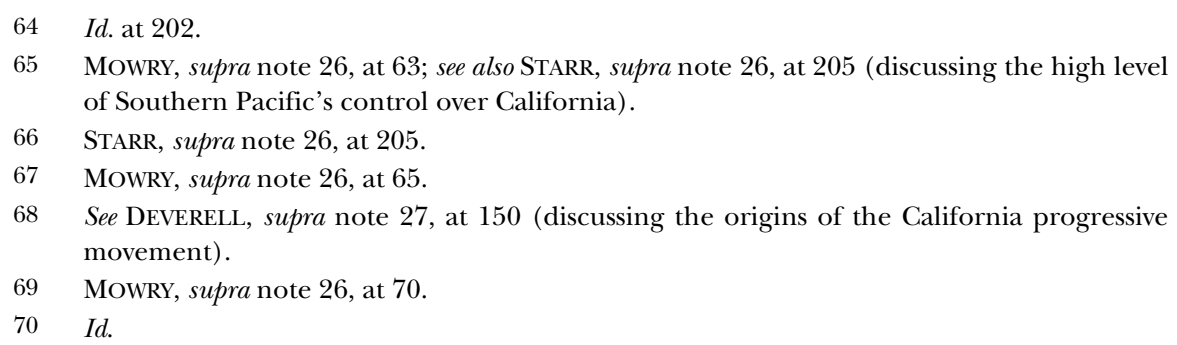


tain form of political economy. If those economic conditions did not obtain, the existence of republican government was threatened. Applying this eighteenth-century logic to California, we can infer that constitutionalism in the Golden State was under siege from the beginning. By this logic there was too little available farmland and an urban area (San Francisco) that was far too large. ${ }^{71}$ This analysis can be pushed further. Eighteenth-century republican theory could not take the measure of corporate power. According to Eldon Eisenach, leading progressive social thinkers did not (and could not) turn to the American constitutional tradition for help. ${ }^{72}$ The eighteenthcentury inheritance was too meager to be of much use in new circumstances.

Whether judged by the standards of the eighteenth or early twentieth century, then, the California constitutional system came up short. In California, the conditions for republican government did not obtain. Further, the giant corporation had intruded into the constitutional sphere. There was no obvious way to "check and balance" the power of the Southern Pacific by using the theories of the Founding Generation. California progressives thus had to find their own way.

It should be appreciated that the conclusions reached by progressives in California were shared by their counterparts in other states. ${ }^{73}$ As recounted by historian Thomas Goebel, there was increasing skepticism during the nineteenth century concerning the competence of state legislatures: "Americans severely weakened state legislatures, adopted the popular ratification of new state constitutions and amendments, and increasingly resorted to popular referenda to decide crucial issues. ${ }^{\text {"74 }}$ Direct democracy was the next logical step as corporate influence persisted over the legislative process. ${ }^{75}$ Historian

71 San Francisco had $23 \%$ of the total population of the state in 1890. See DeP'T OF THE Interior, Twelfth Census of the United States, TAKen In the Year 1900, at 2, 432, available at http://www2.census.gov/prod2/decennial/documents/33405927v1_TOC.pdf (reporting California's population as 1,485,053 and San Francisco's as 342,782).

72 See Eldon J. Eisenach, The Lost Promise of Progressivism 106-07 (1994) ("Constitutional law and the leading lights of American legal scholarship were treated by Progressive intellectuals with studied neglect as a kind of fossilized and symbiotic complement to the party system, which, in turn, they treated with studied contempt.").

73 For a careful review of the states that adopted direct democracy in the late nineteenth and early twentieth centuries, see Steven L. Piott, Giving Voters a Voice: The Origins OF THE INITIATIVE AND REFERENDUM IN AMERICA (2003).

74 GOEBEL, supra note 3, at 14.

$75 \quad I d$. at 115 . 
Steven Piott noted the existence of a "sense of overwhelming frustration ${ }^{, 76}$ with the existing political system:

Convinced that their elected representatives had failed to respond to changes that affected their lives as taxpayers, citizens, workers, or farmers, and that they had allowed a disproportionate share of political power to be held by special interests, voters concluded that the nature of political participation would have to be redefined. ${ }^{77}$

However, advocates of direct democracy generally did not reject representative government. They made clear that the devices of the popular initiative and referendum were supplements to representative democracy, not replacements. ${ }^{78}$

John Dinan has examined the general reasons behind the adoption of direct democracy in his comprehensive review of state constitutional conventions. His discussion shows that delegates believed they had good reason to reject the reliance of Madison and the other Founders on representative institutions. "State constitution makers concluded, in the first place, that Madison was too sanguine about the capacity of representative institutions to combat the problem of minority faction." ${ }^{79}$ That is, state legislatures could too easily be dominated by interest groups. Second, the structure of a representative system meant that it was too easy for office holders to feather their own nests at public expense through patronage and the like. ${ }^{80}$ Third, legislatures were refusing to address long-standing issues of public importance. ${ }^{81}$ Dinan concludes: "[T] he adoption of direct democratic institutions at the state level was not the result of instinctive and undeliberative acts, but rather was the product of longstanding concerns about deficiencies in representative institutions and a belief that existing institutional arrangements were incapable of remedying these problems." ${ }^{22}$

This account of the origins of direct democracy in California shows that it was far from an ill-considered deviation from the constitutional tradition of representative government. It was rather a rational response forced by the repeated failure of representative government over a period of decades. This does not establish that direct democracy was the best solution to the problems of representative

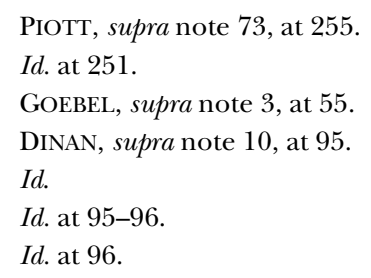


government. But it does show we need to take direct democracy seriously as a meaningful response to the breakdown of the Founders' system of governance.

\section{Direct Democracy AND THE Problem OF TRUST IN GOVERnMENT}

In A Theory of Justice, the great political philosopher John Rawls defined the idea of a well-ordered society as one that generates its own psychological and moral support. ${ }^{83}$ Such a society is said by Rawls to be stable when it is able to generate a sense of justice that is able to counter tendencies toward injustice. ${ }^{84}$ Extending Rawls's concept to the political sphere, we could say that a system of representation is stable when it is able to generate its own support over time. That is, citizens believe the system taken on balance tends to satisfy widely accepted norms of how legislators should behave and how the legislature and executive should make policy.

The history of the origins of direct democracy recounted in Part I supports the conclusion that California's system of representation failed the test of stability after only a few decades. Ultimately, the state legislature was unable to satisfy public expectations and so generate support for the system of representation. In response, California evolved a robust alternative system of governance or constitutional order. The evolution of direct democracy in California (and most likely elsewhere) therefore cannot be understood properly without taking into consideration the failure of representative institutions to accomplish one of their most basic tasks.

Direct democracy may well be seriously flawed on both theoretical and practical grounds. Yet so long as the public views the representative process as equally flawed, there is little likelihood that its popularity will diminish. This suggests that instead of devoting attention solely to the problems with direct democracy, we should inquire into the reasons why its de facto partner, the system of electoral representation, has proven to be so unsatisfactory. That is the focus of this part of the Article.

83 JOHN RAWLS, A THEORY OF JUSTICE 397-98 (rev. ed. 1999).

84 See id. at 398 ("Now a well-ordered society is also regulated by its public conception of justice."). 


\section{A. Direct Democracy in Contemporary California}

Interest in initiatives has waxed and waned in California politics, although it has never disappeared entirely. Thomas Goebel records:

Direct democracy ... immediately became a widely popular and extensively used part of state government. . . During the 1910s, 30 initiatives qualified for the ballot, 35 during the 1920s, and 36 in the 1930s. After 1940, the number of initiatives dropped sharply, to 20 in the 1940s, 12 in the $1950 \mathrm{~s}$, and an all-time low of 9 in the $1960 \mathrm{~s}$, before the rise of new social movements launched a sharp rise after $1970 .{ }^{85}$

He notes that the initiative did not seem to lead to the adoption of radical laws. ${ }^{86}$ Rather, it became an additional instrument of interest group politics. ${ }^{87}$ Interestingly, Goebel concludes: "Because the existence of direct democracy offered pressure groups and citizens additional means to shape the political agenda, California voters were directly confronted with options and policy alternatives not present in many other states." 88

Experienced observers of California politics have recognized that the persistent use of the initiative is linked to the public's low opinion of representative government. ${ }^{89}$ As California journalist Peter Schrag puts it, "During the two decades since the passage of [Proposition] 13, California has been in nearly constant revolt against representative government." ${ }^{90}$ Proposition 13, the most famous initiative in U.S. history, ${ }^{91}$ was the property tax-cutting measure that passed in 1978 by a margin of $65 \%$-to- $35 \%$. It was preceded by a decline in public confidence in government ${ }^{92}$ and "set the stage for the Reagan era, and became both fact and symbol of a radical shift in governmental priorities, public attitudes, and social relationships that is as nearly fundamental in American politics as the changes brought by the New Deal. ${ }^{93}$

GOEBEL, supra note 3, at 141.

Id. at 148 .

Id. at 153 .

Id. at 171 .

89 For a study that links the initiative to ongoing political distrust, see BALDASSARE, supra note 7 , at 12-13, 46-53.

90 SCHRAG, supra note 4 , at 9-10.

91 See Todd Donovan \& Shaun Bowler, Responsive or Responsible Government?, in CITIZENS AS LEGISLATORS, supra note 1, 249, 254.

92 See Mark Baldassare, A California State of Mind: The Conflicted Voter in a CHANGING World 45-46 (2002) ("We believe that the main factor in explaining the tax revolt is distrust in government."). 
High property taxes had been a political issue in California for roughly a decade prior to the passage of Proposition $13 .^{94}$ There was therefore no question of a sudden new issue for state legislators. In the end, the state legislature and political leaders proved unresponsive on an issue critical to voters. ${ }^{95}$ This "reinforced the public's scorn for the legislature and government in general and created a vacuum that made the passage of Proposition 13 possible, even likely." ${ }^{96}$ Despite years of controversy over the effects of Proposition 13, it continues to be popular and resonates with voters as a valuable limit on government. $^{97}$

The passage of Proposition 13 created a new era for direct democracy in California. Other ballot propositions that restricted the ability of state government to tax and spend followed quickly. ${ }^{98}$ According to Elisabeth Gerber, "Between 1974 and 1990, California voters considered 73 statewide initiatives, of which 32 passed. These initiatives covered policy areas as diverse as taxation, insurance regulation, government reform, gambling, environmental policy, criminal law, and school funding." ${ }^{99}$ Not all initiatives led in the direction of less government. Environmental initiatives were popular in the 1970s, such as the much noted Coastal Zone Protection Act, a temporary measure that was later replaced by legislation. ${ }^{100}$ Here again, the perception was that the state legislature had proved incapable of addressing an important policy problem. ${ }^{101}$

94 See AllswANG, supra note 1, at 102-09 (detailing the history of tax-reform initiatives and propositions in the years immediately prior to the passage of Proposition 13).

95 See SCHRAG, supra note 4, at 142-45 (describing the legislative inertia on tax reform in the face of popular political pressure).

96 AllswANG, supra note 1 , at 109.

97 See BALDASSARE, supra note 7, at 88-91 (showing that "only one in four Californians" feel that Proposition 13 negatively affected government services).

98 See AllswANG, supra note 1, at 109-19 (detailing efforts by anti-tax activists in the wake of Proposition 13); Bruce E. Cain et al., Constitutional Change: Is It Too Easy to Amend Our State Constitution?, in CONSTITUTIONAL REFORM IN CALIFORNiA, supra note 13, at 265, 287 (linking the success of Proposition 13 with the success of subsequent tax-reform initiatives).

99 Elisabeth R. Gerber, Reforming the California Initiative Process: A Proposal to Increase Flexibility and Legislative Accountability, in CONSTITUTIONAL REFORM IN CALIFORNIA, supra note 13, at 291 (footnote omitted).

100 See AllswANG, supra note 1, at 136-37 (explaining the origins of the Coastal Zone Protection Act).

101 See id. at 136 (linking the Coastal Zone Protection Act's origin to legislative failures in the early 1970s). 
Another ballot measure that indicated dissatisfaction with the legislature was Proposition 140 in 1990, which established term limits for legislators. "The support for Proposition 140 was a measure of widespread voter dissatisfaction with the workings of state government. Many Californians had become convinced that the state legislature was dominated by powerful special interests and was hopelessly out of touch with the concerns of average citizens." ${ }^{102}$ Californians continued to have a low opinion of the state legislature in the 1990s. ${ }^{103} \mathrm{~A}$ number of initiatives that drew attention were the result of legislative inaction. Reform of bilingual education was blocked in the legislature by politicians responsive to the Latino community and teachers' unions. $^{104}$

As ballot propositions became common, politicians realized they could use them as part of their overall strategy. Governor Pete Wilson used the initiative process to build wedge issues that would help him get reelected (Proposition 187 on illegal immigration) and further his presidential ambitions (Proposition 209 on affirmative action). ${ }^{105}$ Perhaps to Wilson's surprise, Proposition 187 caused a backlash among Latinos, spurring many to register to vote and waking the "sleeping giant" of their political power. ${ }^{106}$

What of the continued use of the initiative process in the present? What survey research shows is that like citizens in the rest of the United States, Californians do not trust their legislature and continue to approve of the mechanisms of direct democracy. ${ }^{107}$ According to political scientist Mark Baldassare, "Voters often prefer to turn to citizens' initiatives to make public policies because of their impatience with the speed of the legislative process and their distrust of the decisions that politicians make." 108 See BRODER, supra note 2, at $169-70$ ("[T] he Democrats who controlled the assembly and
state senate responded to two pressures-leaders of the Latino community ... and the
teachers' unions ....").

RAWLS \& BEAN, supra note 15, at 470-71.

BALDASSARE, supra note 7 , at 84-85.

RAWLS \& BEAN, supra note 15 , at 468.

Id. at 471 . 
To be sure, there has been real frustration and severe criticism directed against the use of the initiative in California. ${ }^{109}$ Tellingly, Baldassare remarks that "many elected officials and political observers would like to see the initiative process just go away."110 This is unlikely because the initiative remains popular. ${ }^{11}$ A detailed 1997 poll showed continued support for the initiative, as "72 percent of respondents said that they were a good thing for the state." be noted that even critics of the initiative admit that the state legislature has not always acted responsibly. ${ }^{113}$

The use of direct democracy continues unabated. In 2005, Governor Arnold Schwarzenegger, himself the product of an unprecedented recall election, ${ }^{114}$ ordered a special election to allow California voters to remake their constitutional order through the initiative process. ${ }^{115}$ Some observers have announced the advent of "hybrid democracy" 116 in which citizens, political parties, and politicians in the legislative and executive branches all use both the legislative process and the tools of direct democracy to achieve their ends. Baldassare concludes:

The roots of this political change are found in four trends evident in recent California politics-the public's support for a populist approach to policy making and their basic distrust of government, along with widespread concerns about the influence of partisanship and special interests on decisions made by their elected representatives. ${ }^{1}$

By this point, these factors should strike us as familiar.

109 See ALLSWANG, supra note 1, at 245-49 ("Most initiative measures are ultimately decided by a small and unrepresentative body of voters.... [whose] laws ... are often badly drawn, extreme, and subject to judicial revocation."). See generally SCHRAG, supra note 4 (describing inadequacies and deficiencies present in California's initiative system). For a recent example of criticism from political science, see Thad Kousser \& Mathew D. McCubbins, Social Choice, Crypto-Initiatives, and Policymaking by Direct Democracy, 78 S. CAL. L. REV. 949 (2005).

110 BALDASSARE, supra note 92 , at 252.

111 See BRODER, supra note 2, at 208 (providing polling numbers illustrative of the popularity of the initiative process).

112 ALLSWANG, supra note 1, at 236.

113 See SCHRAG, supra note 4, at 13, 201-06.

114 For discussion of the recall of Governor Gray Davis and election of Governor Schwarzenegger, see MARK Baldassare \& Cheryl Katz, The Coming Age of Direct DEMOCRACY: CALIFORNia's RECALl AND BEYOND (2008). For a discussion of Schwarzenegger's strategic use of the initiative, see Elizabeth Garrett, The Promise and Perils of Hybrid Democracy, 59 OKLA. L. ReV. 227 (2006).

115 Jordan Rau, Governor Puts Agenda on the Ballot, L.A. TimES, June 14, 2005, at 1.

116 BALDASSARE \& KATZ, supra note 114, at 211; see also Garrett, supra note 1.

117 BALDASSARE \& KATZ, supra note 114, at 219. 
It is thus reasonable to ask how representative government in California got so badly off the track. Table 1 in the Appendix lists illustrative California initiatives that were approved between 1978 and 1998. What this chart suggests is that there were some extraordinarily popular policy measures that were never taken up or acted upon by the state legislature. How could this happen in a representative system? Some initiatives, such as one proposing to designate English as the official language, might have related to an unusual split between mass and elite opinion-leaders of both parties opposed this proposition, yet it was approved by an overwhelming majority. ${ }^{118}$ Still others, such as those addressing term limits, had to do with governance questions on which politicians are unlikely to vote against what they perceive as their own interests.

But the overall record cautions those who take an uncritical stance toward representative democracy. These California initiatives show that representative government fails to represent the popular will on some issues. This suggests that the popularity of direct democracy, particularly the constitutional initiative in California, is as much a story of legislative failure as it is a story of populist uprisings and interest group struggles. The largely hidden dimension of the story of direct democracy in California is that of a state legislature chronically unable to satisfy public expectations. That failure should concern us just as much as the problems of direct democracy, and we should inquire into its sources.

Whatever the precise mix of reasons, it is apparent that the ongoing popularity of direct democracy in California has to do with the failure of the state's political institutions to "re-present" popular opinion. There are obvious similarities in this respect between California and the national government in Washington. Both do not enjoy high levels of public trust and trust tends to be lowest for the legislaturethe institution of government that the Framers thought was the most representative. In what follows, I provide a detailed review of the social science evidence relevant to the decline of trust in the national government. It turns out there is evidence that the decline is linked to the performance of democratic institutions, especially legislatures. This will help illuminate the debate over direct democracy. 


\section{B. The Decline of Trust in Government}

The California experience suggests strongly that there is a link between use of direct democracy and decreased trust in government. As Bruce Cain and Roger Noll argue, "the overriding problem in contemporary American government, whether at the local, state, or federal level, is the perception that government is unresponsive to citizens. The extensive use of the initiative in California reflects this frustration." ${ }^{119}$ Bowling Alone,${ }^{120}$ Robert Putnam's well-known study of civic engagement and social capital, provides a general introduction to the decline of political trust. ${ }^{121}$ "Americans in the mid-1960s were strikingly confident in the benevolence and responsiveness of their political institutions." ${ }^{222}$ But in contemporary times, the situation is reversed. "In the 1990s roughly three in four Americans didn't trust the government to do what is right most of the time." ${ }^{, 23}$ As Putnam describes:

In April 1966, with the Vietnam War raging and race riots in Cleveland, Chicago, and Atlanta, 66 percent of Americans rejected the view that the people running the country don't really care what happens to you. In December 1997, in the midst of the longest period of peace and prosperity in more than two generations, 57 percent of Americans endorsed that same view. ${ }^{124}$

Gary Orren observes that changes in political leadership have not made a difference. ${ }^{125}$ "For three decades, administrations have come and gone, and polling charts have bounced up and down in response to this leader or that policy, yet public trust has tumbled ever downward, regardless of which party has been in power."126 A cynicism that has lasted this long must be "fueled by a deeper set of accumulated grievances with political authority, institutions, and processes in general." ${ }^{127}$ Using evidence from the National Election Studies ("NES"),

119 Bruce E. Cain \& Roger G. Noll, Introduction to Constitutional ReForm In CALIFORNiA, supra note 13 , at 2 .

120 Robert D. Putnam, Bowling Alone: The Collapse and Revival of American COMMUnity (2000).

121 Putnam's chief concern is social trust, the trust we have in other people, not trust in government. Id. at 137. He notes that trust in government is not the same thing as social trust. $I d$.

$122 \quad I d$. at 47.

123 Id

124 Id. (internal quotation marks omitted).

125 Gary Orren, Fall from Grace: The Public's Loss of Faith in Government, in WHY PEOPLE DON'T Trust Government 77, 81 (Joseph S. Nye, Jr. et al. eds., 1997) [hereinafter Why PeOPLe DON'T TRUST GOVERNMENT].

$126 I d$. at 78.

127 Id. at 79. 
Orren shows that trust in government was above $70 \%$ in the late 1950 s and early 1960s. ${ }^{128}$ "Trust fell by a full 15 percentage points from 1964 to 1968, years of intense racial turbulence and turmoil over Vietnam during Lyndon Johnson's administration, and then another 8 percent in the first two years of Richard Nixon's presidency." 29 Orren wonders how this could be the case given that this period was one of great national and legislative accomplishment. ${ }^{130}$

"Public satisfaction [with government] has improved only twice since 1964 ...."131 Once was during President Reagan's first term when he began delivering on his economic promises. ${ }^{132}$ The second occurred in 1996, as President Clinton concluded his first term. ${ }^{133}$ The economy was doing well, the deficit was reduced, and crime rates dropped. ${ }^{134}$ The administration pursued a policy of centrism, which sat well with moderate voters. ${ }^{135}$

Russell Dalton agrees with Putnam and Orren in his review of the evidence. ${ }^{136}$ NES surveys showed high levels of support up until the mid-1960s, when there was a break and a precipitous decline. ${ }^{137} \mathrm{He}$ attributes this to the divisive political issues of the time such as civil rights, Vietnam, and Watergate. ${ }^{138}$ The Reagan presidency temporarily reversed these trends and trust went up in $1984 .{ }^{139}$ But further declines occurred and by 1994, the NES surveys recorded historically low levels of trust. At that point, "[o]nly 22 per cent of the American public felt one could trust the government to do the right thing most of the time, only 20 per cent believed the government is run for the benefit of all, and only 48 per cent thought most government officials were honest." 140

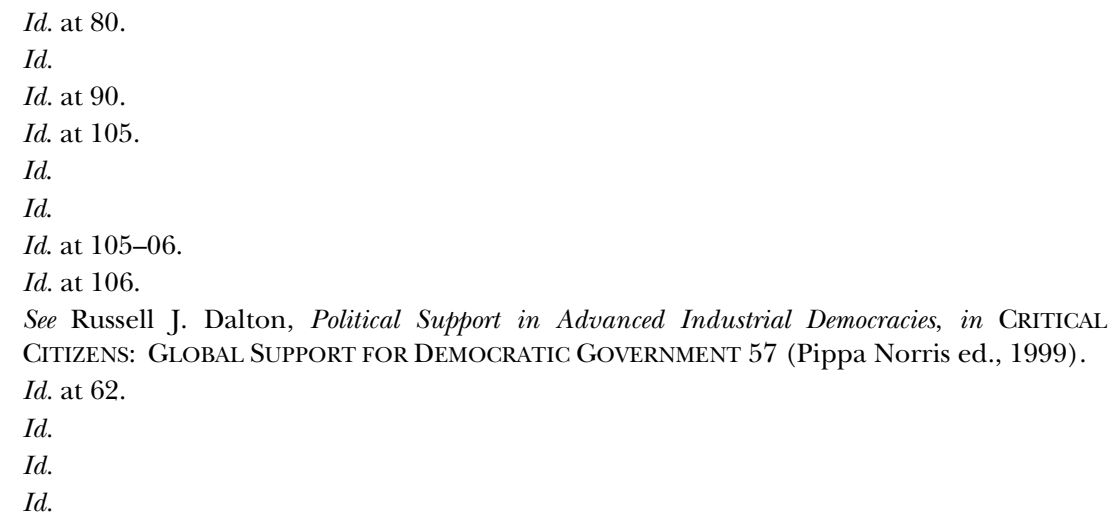


Because so many social scientists rely on them, the NES questions are worth a closer look. The "trust battery" in the NES is composed of four questions: ${ }^{141}$

Trust. How much of the time do you think you can trust the government in Washington to do what is right-just about always, most of the time, or only some of the time?

Waste. Do you think that people in government waste a lot of the money we pay in taxes, waste some of it, or don't waste very much of it?

Interest. Would you say the government is pretty much run by a few big interests looking out for themselves or that it is run for the benefit of all the people?

Crooked. Do you think that quite a few of the people running the government are crooked, not very many are, or do you think hardly any of them are crooked? ${ }^{142}$

From a republican and constitutionalist perspective, the two most relevant questions are those dealing with trust and interest. Whether the federal government is best regarded as activist or limited, it will be difficult for it to accomplish any goal, no matter how worthy, without a modicum of trust. In addition, ideally we want a republican and democratic government to be run for the benefit of all the people, not simply a small self-interested elite.

The NES trust battery was first posed (with some very slight variation in the phrasing of the interest and crooked questions) in the 1958 post-congressional election survey. ${ }^{143}$ The trust and interest questions reappeared in the 1964 survey and have been asked in nearly every survey since (the trust question has been asked in every survey since 1964). ${ }^{144}$ John Alford thus argues that the key measure in the NES is the trust question. ${ }^{145}$ The NES trust question data show that people saying they trust government in Washington most or all of the time increased from 1958 to 1964, then decreased from nearly $80 \%$ in 1964 to just below $70 \%$ in $1966 .{ }^{146}$ There was a further steady drop to around $55 \%$ in 1970 , a leveling off in 1972, then a steep drop

141 I borrow this way of listing the questions from Marc Hetherington. See MARC J. Hetherington, Why Trust Matters: Declining Political Trust and the Demise of AMERICAN LIBERALISM 14 (2005).

$142 \quad I d$

143 The survey is available at the NES website, ftp://ftp.electionstudies.org/ftp/ nes/studypages/1958post/pstq1958.pdf (last visited Feb. 15, 2009).

144 See John R. Alford, We're All in this Together: The Decline of Trust in Government, 1958-1996, in What Is It About GOVERNMENT THAT AmeRICANS Dislike? 28, 29-30 (John R. Hibbing \& Elizabeth Theiss-Morse eds., 2001) [hereinafter AMERICANS DISLIKE?].

$145 \quad I d$.

$146 \quad I d$. at 31 . 
to less than $40 \%$ in $1974 .{ }^{147}$ The most or all of the time score bottomed out in 1980 at less than $30 \% .{ }^{148}$ Trust then rose, peaking at over $40 \%$ in 1984 and leveling off. ${ }^{149}$ But there was a further drop to less than $30 \%$ in 1990 and a new low of near $20 \%$ in 1994, before a small increase to over $30 \%$ in $1996 .^{150}$

The shocking terrorist attacks of September 11, 2001 did not lead to a permanent reversal of this decades-long decline in trust. As Marc Hetherington explains, trust in government went up after $9 / 11$, but it also eroded quickly. ${ }^{151}$ "In June 2002, with the September 11 attacks nine months in the past, trust in government dropped to the same level recorded in the 2000 NES." ${ }^{, 152}$ After 9/11 trust in government increased, but only to Clinton-era levels. ${ }^{153}$ Not exactly a return to the 1960s.

Social scientists have analyzed and debated the reasons for the decline and subsequent minor recovery in levels of trust. What they have not done very often is ask why the trust Americans had in the federal government has never returned to the levels enjoyed in the early and mid-1960s. In addition, they have not focused with sufficient precision on the decline that occurred from 1964 to 1966 . The NES shows trust actually increased from 1958 to 1964 . Why did the decline begin after 1964, a well-known period of great executivelegislative partnership and accomplishment?

The high tide of President Lyndon Johnson's Great Society was the passage of the Voting Rights Act in August 1965. Yet this appears to be the point at which Americans began to lose confidence in the performance of the federal government. Further, Americans apparently feel that no matter what the government has done since, no matter who is in charge, no matter what policies are enacted, nothing has merited a fundamental change in their lack of trust in government. Is the record of government since 1965 really this bad? Are we looking at forty years of unremitting failure?

Perhaps there are reasons for so thinking. But such a permanent decline in a key indicator is arguably a clue about the nature of the constitutional order that took hold in the 1960s and continues today. It has been argued persuasively that the decline of trust does not im-

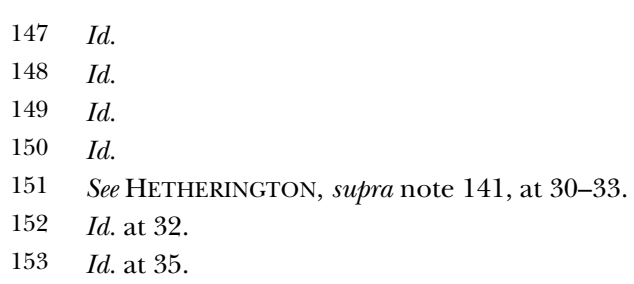


plicate the legitimacy of fundamental constitutional institutions. ${ }^{154}$ There is no evidence that the public disapproves of the Constitution, important constitutional concepts such as the separation of powers, or wishes any constitutional institution abolished or changed significantly. However, a persistent lack of trust can still be regarded as significant from a constitutional perspective. The public may still believe in the Constitution, but relentless distrust puts government, in effect, on a starvation diet in terms of the public authority it needs to operate effectively. ${ }^{155}$

We therefore need to examine the kind of constitutional order that existed in the early 1960s and ask whether existing explanations for the initial decline in trust are adequate. If they are not, we should go further and inquire whether an explanation might be developed that would fit the circumstances of the decline more closely.

\section{The 1960s and the Permanent Decline of Political Trust}

A number of scholars cite Vietnam as the explanation for the initial decline in trust shown in the 1966 NES. In their helpful review of the literature, Margaret Levi and Laura Stoker comment that "the decline in trust from the 1960s to the 1970s was fueled by citizens' reactions to the war in Vietnam, Watergate, and civil rights initiatives." ${ }^{156}$ Joseph Nye argues that it is unlikely that the initial decline of trust in the 1960s was related to poor economic performance. During this period, economic growth was generally strong. ${ }^{157}$ Vietnam and Watergate, he says, help explain how the decline began, but not why it is still going on. ${ }^{158}$ Of course, these are general observations. Watergate did not occupy the attention of the American public until 1973. Vietnam and civil rights fit the timeline more precisely, but there are some problems, as I will discuss below.

\footnotetext{
154 See id. at 14-15; see also Joseph S. Nye, Jr. \& Philip D. Zelikow, Conclusion: Reflections, Conjectures, and Puzzles, in Why PeOPLe DON'T Trust Government, supra note 125, at 253, 277.

155 See John R. Hibbing \& Elizabeth Theiss-Morse, Stealth Democracy: Americans' BeLIEFS ABOut How GOVERNMENT SHOULD WORK 210-11 (2002).

156 Margaret Levi \& Laura Stoker, Political Trust and Trustworthiness, 3 ANN. Rev. POL. SCI. 475, 480-81 (2000).

157 Joseph S. Nye, Jr., Introduction: The Decline of Confidence in Government to WHY PeOPLE DON'T TRUST GOVERNMENT, supra note 125, at 1, 10-11.

158 Id. at 15.
} 
Nye and Philip Zelikow have made some valuable observations about the nature of the explanation that has to be provided for the decline of trust in government. ${ }^{159}$ The explanation has to fit the timing and onset of the decline. They believe that Vietnam and Watergate work quite well explaining the onset of the decline. ${ }^{160}$ But Nye and Zelikow are somewhat careless here. As we have seen, there is a significant decline in trust from 1964 to 1966 . But this is prior to the period in which Vietnam becomes a nationally contentious issue.

Although Vietnam and Watergate were precipitating events, ${ }^{161} \mathrm{Nye}$ and Zelikow argue that there were deeper causes. One was a transformation in the nature of the economy, which they summarize as the "Third Industrial Revolution." dangers of globalization and a loss of control over the economy as a whole. ${ }^{163}$ The second was a change in social-cultural attitudes, stemming from government intervention in social relations, such as civil rights and gender relations. ${ }^{164}$ There were also negative effects from media reporting about government. ${ }^{165}$ They summarize:

The short form of this story is that historical events in the 1960s and early 1970s (Vietnam and Watergate) precipitated a drop in confidence in the U.S. government, but the effects (as well as the cross-national analogues) have been broader and long-lasting because of (1) long-term secular changes in sociocultural attitudes toward authority and traditional social order that came to a head in the $1960 \mathrm{~s}$; (2) profound economic changes caused by the information revolution and globalization; (3) changes in the political process that increased the distance between the political activists and the public; and (4) a more consistently negative approach by the press to government and other institutions. Together, these changes have reinforced a popular culture of bad government. ${ }^{166}$

In an insightful article, John Alford has argued that we need better explanations why the decline in trust occurred. ${ }^{167}$ The decline occurred across all political institutions and all lines of party, ideology, race, income, and region. ${ }^{168}$ Institution-specific and policy-specific explanations are inadequate to explain the decline. ${ }^{169}$ He comments:

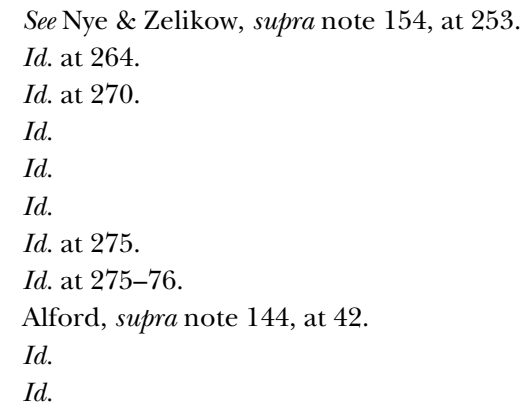


$[\mathrm{M}] \mathrm{y}$ argument here is that it is time to take the details of the actual trends in trust seriously and to stop asserting that we all know why trust in government declined in the sixties and seventies when in fact we have no explanation that is compatible with the details of what we know about the decline itself. ${ }^{170}$

Alford notes that there was no rise in general cynicism in the period in question. ${ }^{171}$ Perhaps distrust of government is the public's "natural state." ${ }^{172}$ This hypothesis would shift the focus to asking why trust in government increased, presumably during the 1950s or perhaps earlier. Alford answers by posing a broad historical explanation. An external threat to the country could cause citizens to rally around the government. ${ }^{173}$ He notes that:

In 1960 over $60 \%$ of the respondents cite foreign policy or defense as the number one problem [facing the nation]. By 1974 this has fallen into single digits and remains there through 1978. Likewise, trust in government takes its dramatic plunge over this same period. ${ }^{174}$

The 1950s and early 1960s, the height of the Cold War, could plausibly be characterized as a period in which Americans perceived an external threat from the Soviet Union and China. Perhaps this was an unusual period during which foreign policy and defense matters took precedence over the normal dominance of domestic issues. But why would a return to domestic issues lead to a decline in trust?

These observations are helpful, if somewhat preliminary. But even these astute scholars do not focus with sufficient care on the 1964-66 period. Why does the decline in trust start here? Vietnam will not work as an explanation. There is no evidence of general public opposition to the war during 1966, the key year in question. ${ }^{175}$ The Gulf of Tonkin Resolution (arguably) authorizing the Vietnam War occurred in August 1964 and President Johnson's fateful decision to escalate the war into a major commitment did not come until July 1965. ${ }^{176}$ The famous hearings held by Senator William Fulbright criticizing the premises of the war were held in January 1966, but did not presage any fundamental shift in public opinion. ${ }^{177}$ There was a nega-

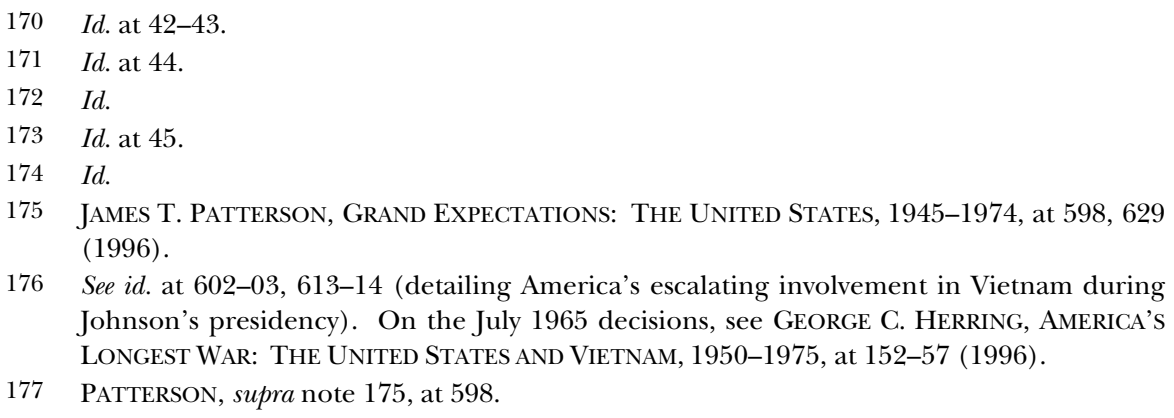

176 See id. at 602-03, 613-14 (detailing America's escalating involvement in Vietnam during Johnson's presidency). On the July 1965 decisions, see GEORGE C. HERring, AMERICA's LONGEST WAR: THE UNITED STATES AND VIETNAM, 1950-1975, at 152-57 (1996). 
tive shift in public opinion in $1967,{ }^{178}$ but as late as mid-1967, a majority of the public still supported the war. ${ }^{179}$

Was this period one in which the government was perceived as doing nothing about important national problems? Of course the opposite is the case. The period in question begins with LBJ's overwhelming electoral victory over Republican candidate Senator Barry Goldwater. Johnson had already swung into action during the summer of 1964 by winning passage of a tax cut, the war on poverty, and the Civil Rights Act. ${ }^{180}$ Johnson followed up his electoral victory with one of the most productive sessions of Congress in history, winning passage of federal aid to education, Medicare and Medicaid, immigration reform, and the Voting Rights Act, as well as various pollution control and natural resources measures. ${ }^{181}$

Perhaps LBJ and the Democratic Congress were wrong to think that all this liberal activism was what the public wanted. Yet with one important exception, there is no evidence that these measures were unpopular. Certainly they were not repealed in forthcoming decades and, indeed, the scope of many of these policy initiatives was extended. The exception is civil rights legislation. If we cast around for a group that was dissatisfied with the course of national policy in this period, it appears Southern whites might qualify. They were the group, after all, whose preferences concerning racial policy were consistently defeated. Marc Hetherington notes: "From 1964 to 1970, when the reach of civil rights legislation was largely confined to the South, southerners were less trustful of the federal government than nonsoutherners, although the gap had begun to close by 1968." 182 Perhaps the initial decline in trust was led by whites uncomfortable with the speed at which the United States was moving into a new era of race relations.

There is historical evidence to support the idea of a white backlash that began during the 1964-66 period. As President Johnson and Congress busied themselves passing the Civil Rights Act of 1964, Alabama Governor George Wallace was shocking liberals with his apparent appeal to voters in such northern states as Wisconsin. ${ }^{183}$ Wallace won particular approval among northern whites for his attacks 
on open housing legislation. ${ }^{184}$ In this same period, California voters passed Proposition 14, repealing the Rumford Fair Housing Act. ${ }^{185}$ Liberals could not explain the passage of Proposition 14 any more than they could explain Wallace's popularity. ${ }^{186}$ It appears relatively clear in hindsight, however, that at least some whites thought antidiscrimination laws were moving too far, too fast. They saw government as taking an aggressive position favoring the rights of blacks over whites, rather than establishing equal justice for all. Whites might also have viewed the August 1965 Watts Riot in Los Angeles as evidence that government was failing in its basic responsibility to maintain order. ${ }^{187}$

So it is likely that not everyone was happy with the course of national policymaking from 1964 to 1966 . Some whites might have begun to express less trust toward the national government because of the change in racial policy. But while these reactionary views may help explain the initial decline in trust in government, they do not explain its long duration. Both racial policies and views have evolved since the mid-1960s, yet trust in government remains low. What is required is an account that would help explain both why trust declined in the initial 1964-66 period, and also why it did not recover the substantial ground lost during the $1964-80$ period. We need to maintain a dual focus on both the key initial period of 1964-66 and the subsequent fact that trust never returned to the levels enjoyed in the early 1960s.

In developing such an explanation, I believe Alford is right to frame the inquiry in historical terms. The NES data suggest that the nation moved from a high-trust to a low-trust era within a short span of time. Further, the initial decline in trust and subsequent duration of the decline cannot be explained through an appeal to discrete factors such as unpopular wars or political scandals. Something else shifted in the background of American politics that created the conditions for a long-term decline in political trust. I suggest that atten-

184 Dan T. Carter, The Politics of Rage: George Wallace, the Origins of the New CONSERVATISM, AND THE TRANSFORMATION OF AMERICAN POlitics 207 (1995).

185 See Matthew Dallek, The Right Moment: Ronald Reagan's First Victory and the DeCisive TURning POINT IN AMERICAN POLITICS 46-61 (2000) (narrating the account of passage of Rumford law and subsequent repeal by Proposition 14). Proposition 14 was overturned by the Supreme Court in Reitman v. Mulkey, 387 U.S. 369 (1967).

186 See DALLEK, supra note 185 , at 60.

187 See PATTERSON, supra note 175, at 448-49 (giving several examples of the social unrest in the 1960s, including the Watts riot). 
tion should be paid to shifts in the nature of the political and constitutional order.

\section{The Constitutional Order and the Decline of Political Trust}

My argument is that the decline of political trust is in part the result of a mismatch between public expectations rooted in the Constitution itself and what the political system can provide. Trust in government was likely high during the 1940s (although empirical evidence is slim) and 1950s, but this period of strong civic belief was in a sense artificial. It was being produced by the consensus behind World War II and the Cold War. Once the Cold War began to ebb after 1963, conditions were ripe for a return to "normal" politics. Unfortunately, this return occurred in a period of extraordinary domestic political conflict. Because the American public does not favor a politics ridden with conflict, ${ }^{188}$ trust in government began to decline. Further, trust stayed low, relative to the levels attained in the 1950 s and early 1960s, because it became apparent that conflict was the normal condition of domestic politics. ${ }^{189}$

It may be the case that a lack of trust in government is the "natural" condition of the American polity and that the period of high trust and confidence in government in the middle of the twentieth century was therefore anomalous. While I think there is some truth in this, the crucial point, the constitutional point, is that low trust can lead to instability in a constitutional order characterized by activist government. To put the point another way, low trust is nonfunctional for an activist constitutional order. In such an order, low trust does not lead to a restoration of limited government. It leads rather to bad government and poor policy.

There are some similarities between this argument and a recent thesis about the decline of liberalism made by historian H.W. Brands. ${ }^{190}$ By "liberalism," Brands means, roughly, the belief that big government can solve social problems. Brands argues that "the liberalism that characterized the period from 1945 until the early 1970s was anomalous by the standards of American history. Moreover, this anomaly was chiefly the consequence of the predominant feature of

188 See the discussion in Alan Wolfe, One Nation, After All: What Middle-Class Americans Really Think About: God, Country, Family, Racism, Welfare, IMMigRATION, HOMOSEXUALITY, WORK, THE RIGHT, THE LEFT, AND EACH OTHER 285-86 (1998).

189 I sketched an argument similar to this one in GRIFFIN, supra note 21, at 194-201. 
global politics at the time-the Cold War."191 During World War II and the Cold War, Americans put their traditional distrust of government to one side. ${ }^{192}$ The Cold War, especially in its first decade, was perceived as a real war, and in wartime, the American people rally around the national government. ${ }^{193}$ From Brands's perspective, the decline in trust was triggered by Vietnam. High levels of trust in government were an artifact of the Cold War and "when the Cold War cracked up in Vietnam, it shattered the consensus, ravaged popular faith in government, and scorched the earth from which the liberal agenda had sprung." 194

Brands's account is valuable in emphasizing the role of World War II and the Cold War in creating the conditions that led to increased trust in government. A number of scholars agree that World War II sparked high levels of trust in government. Robert Putnam points to the special nature of the national experience during World War II. ${ }^{195}$ There was an "extraordinary burst of civic activity" during and after the war because it involved "shared adversity and a shared enemy." 196 Richard Neustadt contends that trust was high during World War II and in the postwar years. ${ }^{197}$

While I do not agree that Vietnam was the key event that triggered the loss of trust in government, ${ }^{198}$ Brands does provide a clue about the crucial transition period of 1964-66. He notes that the Cold War reached a new pitch of intensity with the 1962 Cuban missile crisis. ${ }^{199}$ After the crisis, both sides took steps to defuse tensions and this led to a perception, among liberals at least, that the Cold War had changed and that domestic issues could assume a new priority. ${ }^{200}$ It is likely, then, that as the initial period of decline began after 1964, the Cold

\footnotetext{
191 Id. at $\mathrm{x}$.

192 Id. at $\mathrm{x}-\mathrm{xi}, 47$.

193 See id. at 65-66 (noting the general acceptance of a big federal bureaucracy during the Cold War).

194 Id. at 125

195 PUTNAM, supra note 120, at 268-72.

196 Id. at 268.

197 Richard E. Neustadt, The Politics of Mistrust, in Why People Don'T Trust Government, supra note 125 , at $179,191$.

198 In general, Brands weakens his argument by not taking into consideration the NES and other survey evidence. He presents President Reagan as presiding over a further decline in trust, when the Reagan years were one of the few periods in which trust increased. BRANDS, supra note 190, at 140, 150-51.

199 See id. at 83 (describing the crisis as "the most terrifying hundred hours in the history of the Cold War").

200 See Allen J. Matusow, The Unraveling of America: A History of Liberalism in the 1960s, at 377 (1984).
} 
War was no longer delivering the same measure of support for the government's actions.

In many respects, Marc Hetherington's detailed study of political trust supports my argument. Hetherington explains the decline of activist government in terms of the decline of trust in government. ${ }^{201}$ He uses the NES and other data to show that "declining political trust has played the central role in the demise of progressive public policy in the United States over the last several decades." ${ }^{202}$ Hetherington discounts the role of ideological change, contending little evidence exists that there has been a conservative turn in public opinion. ${ }^{203}$ When Americans actually benefit from government programs, they support them. ${ }^{204}$ But people need to trust the national government in order for that government to undertake the sort of programs that benefit minorities by using taxes and benefits drawn from majorities, such as antipoverty and race-targeted programs. ${ }^{205}$ Hetherington comments, "While the early to middle 1960s were perhaps anomalous in their high levels of public trust, they allowed policymakers great leeway in proposing and implementing federal solutions to America's problems." 206

A proactive government able to address policy problems as they arise must be underwritten by the authority granted by public trust in government. This trust might be thought of as a willingness to grant the benefit of the doubt. Roughly since the mid-1970s, the American public has been unwilling to grant that benefit, thus placing a sort of invisible limit on the ability of government to act.

Why would a renewed emphasis on domestic issues result in a permanent decline in trust? Here we should turn to two pathbreaking studies on the "process preferences" of Americans done by John Hibbing and Elizabeth Theiss-Morse. ${ }^{207}$ Their approach is unusual and valuable in that they focus on how Americans want public business done, rather than asking about their policy preferences. This

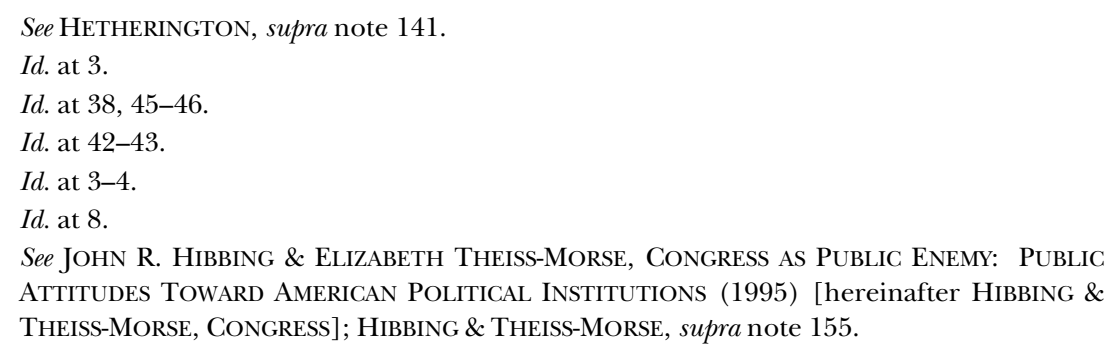


means their studies provide insight into the constitutional preferences of Americans concerning how politics should be structured. ${ }^{208}$

Hibbing and Theiss-Morse contend that "people's support for the political system is influenced at least as much by the processes employed in the political system as by the particular outputs emanating from the process. Policy is important, but the public's perceptions of how that policy was arrived at also matters." ${ }^{209}$ This means that it is possible for trust in government to be influenced by how government operates. Hibbing and Theiss-Morse's results suggest that trust is low because Americans do not like the normal processes of democratic government. As they put it:

Americans tend to dislike virtually all ... democratic processes .... They dislike compromise and bargaining, they dislike committees and bureaucracy, they dislike political parties and interest groups, they dislike big salaries and big staffs, they dislike slowness and multiple stages, and they dislike debate and publicly hashing things out, referring to such actions as haggling or bickering. ${ }^{210}$

In short, Americans do not like political conflict. Hibbing and Theiss-Morse's first study was of Congress, often thought of as the most democratic, representative, and responsive branch of government. But the study participants did not see it that way. It is well known that Americans tend to have negative views of Congress in general even as they have positive views of their own representative. ${ }^{211}$ Care must be taken in interpreting this result. Americans may in fact have a positive view of "Congress," the constitutional institution. But crucially, they have a poor opinion of members of Congress when they act collectively. ${ }^{212}$ Among the three constitutional institutions, Congress is the least approved. ${ }^{213}$

Where does Congress go wrong? Hibbing and Theiss-Morse's results show that Americans believe that members of Congress have been corrupted by special interests. ${ }^{214}$ Americans tend not to identify with special interests, whether of the left or right. Instead, they see interest groups as the favored clients of the Washington "insider" sys-

\footnotetext{
208 In employing their results, my assumption is that it is plausible that their results, obtained from surveys done in the 1990s, have something to tell us about the reaction of Americans to the events of the mid-1960s. That is, it is reasonable to assume that the process preferences of Americans have remained relatively stable over time. HibBING \& THEISS-MORSE, CONGRESS, supra note 207, at 14. 
tem of politics. ${ }^{215}$ The public hates the very idea of insiders. "It reminds them of their own outsider status and it opens the possibility that benefits will be distributed in something other than a just and equitable fashion." ${ }^{16}$ From the perspective of constitutional history, there is a tinge of Jacksonian political values here. It is also appropriate to note an echo of the themes present in late nineteenth century California politics.

The broader picture is that Congress is the most detested branch because it is the most visible branch. ${ }^{217}$ But what is visible is the standard legislative politics of conflict and debate, followed by compromise and logrolling. The public loathes each and every element of this normal democratic process. ${ }^{218}$ People who have more political knowledge are more likely to be tolerant of debate and compromise. But even Americans who are relatively expert about politics detest political professionalization and interest groups. ${ }^{219}$ Hibbing and TheissMorse conclude that "[a] surprising number of people, it seems, dislike being exposed to processes endemic to democratic government." ${ }^{220}$ Americans appear to be convinced "that we can have a democracy without uncertainty, conflicting options, confusion, bargaining, or compromises for solutions."221

Hibbing and Theiss-Morse followed up their study of Congress with a study of American attitudes toward government in general. ${ }^{222}$ They contend Americans want "stealth democracy," an efficient democracy that does not require their active participation. ${ }^{223}$ Their study shows that while people do not generally want to be active in government, they do want it to be available, accountable, and open when they do wish to become involved. ${ }^{224}$ However, normally what

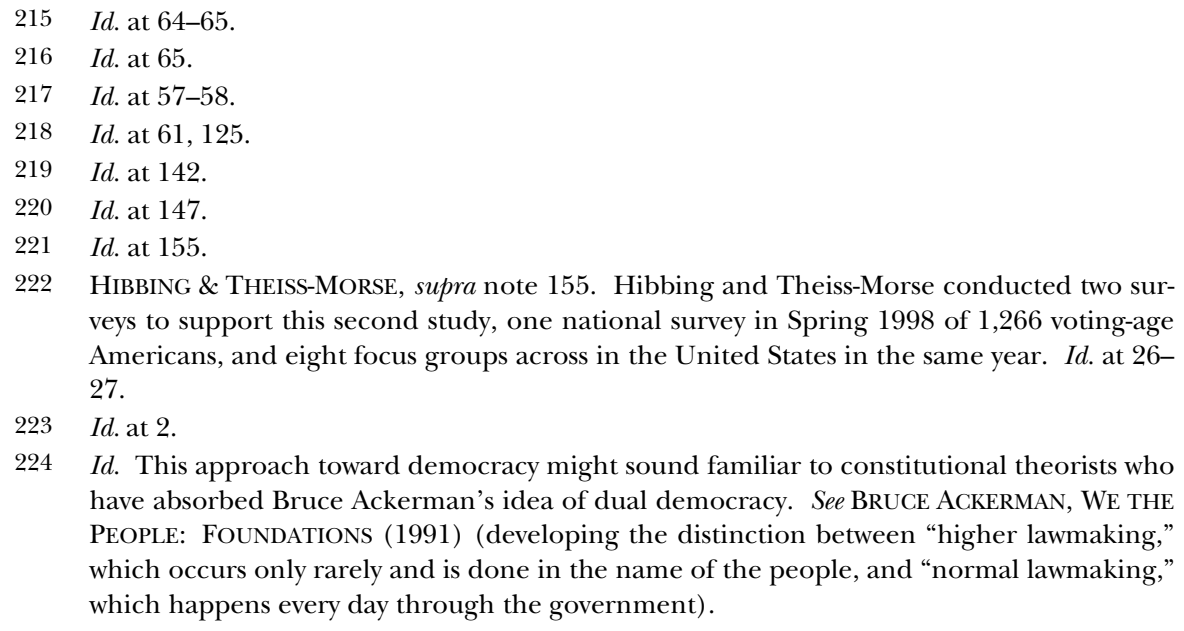

224 Id. This approach toward democracy might sound familiar to constitutional theorists who have absorbed Bruce Ackerman's idea of dual democracy. See Bruce Ackerman, We the PEOPLE: Foundations (1991) (developing the distinction between "higher lawmaking," which occurs only rarely and is done in the name of the people, and "normal lawmaking," which happens every day through the government). 
people want from government is consensus, unity of purpose, and a lack of concern for special interests, not accountability and responsiveness. ${ }^{225}$ "The processes people really want would not be provided by the populist reform agenda they often embrace; it would be provided by a stealth democratic arrangement in which decisions are made by neutral decision makers who do not require sustained input from the people in order to function." ${ }^{226}$

With respect to trust in government, Hibbing and Theiss-Morse propose that it is driven more by perceptions of process than by policy outcomes. After all, studies have shown that voters are usually interested in just a few issues and people do not have a well-developed set of policy preferences. ${ }^{227}$ Further, policy outcomes do not seem to explain variances in trust in government. ${ }^{228}$ In the $1990 \mathrm{~s}$, for example, "victory in the Cold War and the incredibly strong economy from late 1992 to mid-1997 brought some of the worst marks for dissatisfaction with government since the beginning of systematic public opinion data." ${ }^{29}$

Nearly $70 \%$ of the respondents in the 1998 Hibbing and TheissMorse survey felt that the political system was not responsive to their interests. ${ }^{230}$ This was despite the fact that most Americans perceive government policies to be moderate, in line with their own preferences. ${ }^{231}$ Nonetheless, "[m]any people who have no particular problem with the policies produced by the government are tremendously dissatisfied with that government. ${ }^{\not 232}$ Dissatisfaction with government is thus not based on policy disputes, but rather on how the process of government works.

Hibbing and Theiss-Morse argue that the low opinion Americans have of democratic processes is driven by the misperception that their policy interests and preferences are similar to the majority of Americans. The public believes there is a consensus on public policy, but a flawed process in Washington is frustrating the true interests of the people..$^{233}$ People believe that "special interests and their cronies

HIBBING \& THEISS-MORSE, supra note 155 , at 4.

Id. at 7 .

Id. at 21-22, 150

Id. at 25, 63-64.

Id. at 64 .

Id. at 27 .

Id. at 29 .

Id. at 34 .

Id. at 38 . 
in the political parties and in government have commandeered the entire process." ${ }^{234}$

More positively, what Americans want from the political process is to have decisions made unselfishly, without influence from special interests. ${ }^{235}$ The American people want policymaking elites to be disinterested and not self-serving. ${ }^{236}$ So if it were possible to have government "by non-self-interested elites, ${ }^{, 237}$ Americans would readily accept this alternative.

In light of these process preferences, it will not be surprising to legal scholars that in the 1998 survey done by Hibbing and TheissMorse, the Supreme Court was the most popular institution of government. ${ }^{238}$ Americans are well disposed toward government institutions as a whole, but they tend to dislike Congress and the federal government the most, the Supreme Court and state governments the least. $^{239}$ True, Americans do not want major changes in our system of government, but they define "major" in a different way from political elites. "Major" would be throwing democracy overboard for authoritarian government. On this conception, the banning of all interest groups would not count as a major change and many Americans find the idea of such a ban attractive. ${ }^{240}$

The general picture that emerges from the Hibbing and TheissMorse studies is of an American public that wants government by consensus and dislikes political conflict of any kind. Hibbing and Theiss-Morse contend that Americans falsely believe that there is a consensus on the policy goals the country should have and the means to achieve them. ${ }^{241}$ "Consequently, when it is apparent that the political arena is filled with intense policy disagreement, people conclude that the reason must be illegitimate-namely, the influence of special interests." ${ }^{242}$ The belief in a false consensus must be stated carefully, however. ${ }^{243}$ Hibbing and Theiss-Morse note that " $[\mathrm{t}]$ he false consensus that really hurts people's views of the government is not the one that leads people to believe that everyone shares their policy belief

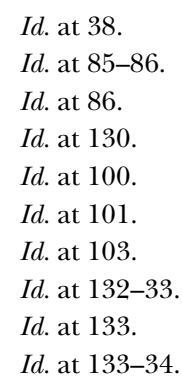


but the one that says everyone shares their lack of concern about most of the issues the government is addressing." ${ }^{24}$ That is, from the perspective of the average citizen, national politics is full of intense and apparently endless conflict over issues that are unimportant. ${ }^{245}$ No wonder citizens are frustrated with government.

Americans thus dislike debate, compromise, and conflict. ${ }^{246}$ "In fact, people believe the very existence of conflict is a sign that elected officials are out of touch with ordinary Americans." 247 Large percentages of the public would view favorably governing structures that are not democratic, such as leaving decisions to nonelected experts. ${ }^{248}$ Hibbing and Theiss-Morse call this method of government "stealth democracy." "The goal in stealth democracy is for decisions to be made efficiently, objectively, and without commotion and disagreement." ${ }^{250}$

The studies by Hibbing and Theiss-Morse raise many interesting and important questions about American democracy and have clear implications for the debate over direct democracy. In terms of the discussion in this part of the Article, I am concerned only with the implications of their findings for the two aspects of the decline of trust in government identified earlier: Why did trust begin declining before the traumas of Vietnam and Watergate, and why was the decline permanent in the sense of never fully regaining the ground lost?

These studies suggest that trust declined because American politics moved from a regime that was relatively consensual to one that was riven by conflict. It is not news that the 1950 s was a time of consensus in American politics. Certainly American intellectuals thought so at the time. But historians have also reached this judgment in hindsight. ${ }^{251}$ The sense of consensus had several sources. One was President Eisenhower's acceptance of the basic structure of the New Deal, including social security. ${ }^{252}$ Another was Eisenhower's style of leadership, "evok[ing] a quiescent mood of stability and consen-

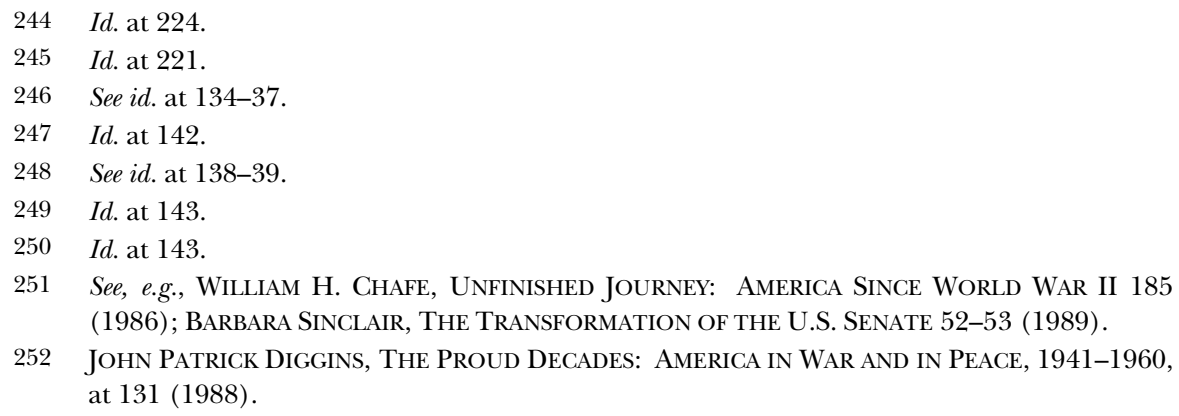


sus." ${ }^{253}$ Certainly politicians did not hear many complaints about the economy, which was undergoing a period of tremendous growth. ${ }^{254}$ If the 1950s "gave Americans a sense of pride in themselves and confidence in the future, ${ }^{, 255}$ historians have also noted a change in the national mood at the end of the Eisenhower administration and extending into the early 1960s, one that possibly heralded a new period of activist government. ${ }^{256}$ It seems Americans were undergoing a period of transition, but the shape of the new politics was unclear.

It is worth noting that in substantial measure, the political consensus of the 1950s was artificial. The normal channels of political dissent and protest were smothered by the fear of communism and the politics that fed from this fear, usually called McCarthyism. ${ }^{257}$ As "the most widespread and longest lasting wave of political repression in American history," ${ }^{258}$ McCarthyism had a significant effect on American politics. Any viewpoint that was to the left of the Democratic party was suspect. Hence, the range of political debate was narrowed. ${ }^{259}$ Americans living through this period might have justifiably acquired the idea, expressed somewhat later by President Kennedy, that politics was simply a matter of administration, not of fundamental ideological conflict.

To understand this transition within a constitutional framework, we need to recall the background in which it occurred. The reigning constitutional order was that of the New Deal. The national government's assumption of responsibility for regulating the economy during the New Deal had profound implications for American constitutionalism. The activism of the government in addressing the Great Depression encouraged citizens to look routinely to national politics for solutions to social problems. ${ }^{260}$ Once the constitutional barriers to

Id. at 153 .

Id. at $178-81$.

Id. at 348 .

Id. at 348-50; see also JOHN MORTON BLUM, YeARs OF DisCORD: AMERICAN POlitics AND SOCIETY, 1961-1974, at 3-13 (1991).

257 See generally ElLEN SCHRECKER, MANY ARE THE CRIMES: MCCARTHYISM IN AMERICA (1998) (assessing the impact of anti-communist sentiments across a variety of events and institutions).

$258 I d$. at $\mathrm{x}$.

259 See id. at 359-95 (showing how anti-communist sentiments suppressed political debate and diversity of opinion).

260 See, e.g., BARRY D. KARL, THE UnEAsy StATE: THE United STATES From 1915 TO 1945, at 226-27 (1983); Sidney M. Milkis, The President and the Parties: The Transformation of THE American PARTy System Since the New DeAl 150 (1993). 
the expansion of the national political agenda were removed, there were no limits on the kind of issues the national state might consider.

Thus, to widen the focus somewhat, the 1960-66 period was a key moment of transition within the New Deal constitutional order. There was a growing sense that the boundaries of political change had been drawn too tightly. McCarthyism and the loyalty security programs that went with it had ebbed. The perceived external threat from the Soviet Union lessened after 1963. Americans were ready for more consensual progress, but instead they encountered a contentious national politics. ${ }^{261}$ In the midst of the transition to a politics of conflict and polarization, Americans began reacting negatively by indicating a lack of trust in government. As political conflict continued and intensified in the late $1960 \mathrm{~s}$, Americans responded by driving levels of distrust to new lows. The era of permanently low trust in government had arrived.

In many respects, however, citizens retained a political worldview characteristic of an earlier constitutional regime. Perhaps there were some resemblances between what Americans expected from politics in the 1950s and what they expected in the 1790s. But it is more likely that the Jacksonian era, with its emphasis on political equality, combating privilege, and hostility to the "interests," is the nearest ancestor of the kind of worldview described in the Hibbing and TheissMorse studies. This mismatch between political worldview and the interest group state established in the New Deal could persist because of the political consensus behind President Roosevelt's efforts to fight the Great Depression and win World War II. Once that consensus eroded, Americans began to glimpse the real nature of politics in a state full of interest groups jostling for advantage, lobbyists seeking influence, polarized single issue organizations, and politicians brokering deals among them all.

The turmoil in American politics after the 1950s suggests that there is no such thing as a democratic politics of consensus as a normal state of affairs. Thus, when a consensus exists on a wide range of policy issues in a democracy, it is reasonable to infer that it is being maintained by an unusual external threat (such as during a war), or is the result of a constricted political agenda produced by economic, social, or legal restrictions on political participation. The Cold War produced a bipartisan consensus in foreign affairs because an external threat was perceived clearly by elites and the public. It also had

261 For a review of the polarization of politics in the 1960 s and early 1970 s, see PATTERSON, supra note 175 , at 442-57, 547-57, 565-68, 637-77, 706-09, 730-35. 
an important effect in limiting the further extension of the New Deal domestic policy agenda, as unions and other liberal organizations were forced on the defensive during the era of McCarthyism. ${ }^{262}$ In addition, the restrictions on the electorate enacted in the PopulistProgressive eras remained in force. ${ }^{263}$ All of these factors maintained the World War II consensus long after the fighting had ended.

Consider, then, how many roads intersected in the 1960s. The legal restrictions on effective political participation were for the most part abolished. There was renewed attention to domestic issues in the context of long-standing grievances by minorities. Consensus disappeared and polarization increased. To put it another way, the United States experienced full-fledged national democratic politics for the first time in its history. Americans responded to the political effects of this tremendous historical achievement with something like disgust. Not that Americans are opposed to democracy, the right to vote, or the principles of the civil rights movement. But the Hibbing and Theiss-Morse studies show that Americans do not understand that making politics more democratic does not make it more consensual. In fact, the opposite is the case.

\section{COMING TO TeRmS WITH DIRECT DEMOCRACY}

In this final Part, I will discuss direct democracy and "California constitutionalism" in light of the decline of trust in government. I hope it is apparent that instead of regarding direct democracy as deviant, it might be more appropriate to ask why it does not exist on a national level. The answer probably lies with the greater difficulty in amending the federal Constitution. Nevertheless, the problems with representative government in California are national problems. Citizens do not have much respect for the legislative process and seek alternatives if they have the chance. For reasons of history at least distantly related to the problems citizens have with contemporary politics, Californians have been afforded a chance denied to citizens nationwide.

Again, this is not to deny that direct democracy has serious shortcomings. Before briefly setting forth a number of the more significant criticisms, I hope it is evident why I will not devote attention to the familiar charge that direct democracy is inconsistent with the 
Founders' vision of republican government. ${ }^{264}$ This sort of sweeping criticism ignores the reality that we have allowed extensive formal constitutional change at the state level to supplement the original designs of the Founding Generation. It also ignores that the latter-day framers of direct democracy had good reason to conclude that representative government had fallen short and required reform.

As the twentieth century gave way to the twenty-first, it was evident there were at least three substantial lines of critique against the use of direct democracy, particularly in the initiative, in California politics. First, critics argued that rather than create a better form of popular politics, the initiative had become simply another venue for interest groups to pursue their goals. ${ }^{265}$ Interest groups, not voters, seemed to dominate initiative politics. Second, there were persistent worries that initiatives tend to work against the interests of minorities, particularly racial and ethnic minorities. ${ }^{266}$ Divisive and often bitterly contested initiatives relating to English as an official language (Proposition 63), abolishing affirmative action (Proposition 209), ${ }^{267}$ restricting illegal immigration and its effects (Proposition 187), and abolishing bilingual education (Proposition 227) lent credence to this idea. ${ }^{268}$ Third, critics charged that the initiative led to a defective, indeed self-defeating, system of governance. ${ }^{269}$

While it is not my purpose to defend direct democracy against these generally sound criticisms, it is worth noting that critics have had a hard time identifying flaws of direct democracy that are truly unique in the sense that they identify a clear difference between it and representative government. After all, undue influence by inter-

\footnotetext{
264 See, e.g., BRODER, supra note 2.

265 See, e.g., Todd Donovan \& Shaun Bowler, An Overview of Direct Democracy in the American States, in CitIZENS AS LEGISLATORS, supra note 1, at 1, 12.

266 Id. at 16-18; see also Sylvia R. Lazos Vargas, Judicial Review of Initiatives and Referendums in Which Majorities Vote on Minorities' Democratic Citizenship, 60 OHIO ST. L.J. 399 (1999) (noting that the referendum process tends to work against minorities and suggesting a formula for reviewing such initiatives based on whether they affect the group's ability to participate in the political process).

267 For an account of the Proposition 209 campaign, see LYDIA CHÁvEZ, THE COLOR BIND: CAlifornia's BATtLE TO END AfFirmative ACTION (1998).

268 See, e.g., Kevin R. Johnson, The Devastating Impact of the Initiative Process on Latino and Immigrant Communities (UC Davis Research Paper No. 133, 2008), available at http://ssrn.com/abstract=1103607.

269 See generally ScHRAG, supra note 4. Political scientist Elisabeth Gerber described the governance problem in California: "Voters perceive government as unaccountable so they pass initiatives to restrict its actions. This constrains government and prevents it from responding to the state's pressing demands, which further angers voters and provokes them to pass even more stringent constraints." Id. at 216 (internal quotation marks omitted).
} 
est groups is a problem that plagues all legislatures in the United States. In addition, as John Matsusaka points out, "the fact that narrow interests dominate the initiative process ... does not necessarily imply that the final outcomes are nonmajoritarian." 270 Voters are free to reject initiatives sponsored by interest groups and have done so. ${ }^{271}$ They do not often have that chance with respect to legislative measures sponsored by the same groups. Careful historical investigation has revealed that interest group involvement with initiatives is nothing new and has been present almost from the beginning. ${ }^{272}$

With respect to minority interests, while I do not wish in any way to minimize the real concerns behind this criticism, I note that as a general matter, it would be difficult to show that direct democracy has a record worse than the ample examples of violations of rights by elected officials. For example, Jim Crow laws segregating African Americans were passed by state legislatures. ${ }^{273}$ There is some evidence that minority voters in California support the institutions of direct democracy. ${ }^{274}$

In response to these and other criticisms, there is no shortage of proposals for reform of direct democracy, especially the initiative. ${ }^{275}$ Whatever the right mix of reforms of direct democracy and the legislative process, I hope I have shown that they must be considered together. What is probably required is not tinkering, but major constitutional reform.

On the other side, how might legislatures be reformed? The survey research on Congress reviewed in Part II suggests in general that legislators must come to grips with the reality that they are always on trial as far as ordinary citizens are concerned. ${ }^{276}$ Political scientists David Brady and Sean Theriault have argued that the public has little tolerance for rules that allow legislators to escape accountability for taking positions on difficult issues or the consistent use of hyperbolic

\footnotetext{
270 MATSUSAKA, supra note 1 , at 12.

271 See GoEBEL, supra note 3, at 195 ("It is apparently much easier to persuade voters to vote against a controversial idea than it is to make them endorse it.").

272 See David McCuan et al., California's Political Warriors: Campaign Professionals and the Initiative Process, in Citizens as Legislators, supra note 1, at 55; see also GOEBEL, supra note 3, at $193-97$.

273 Id. at $91-93$

274 MATSUSAKA, supra note 1 , at 117-18.

275 See, e.g., Garrett \& McCubbins, supra note 1; see also Michael S. Kang, Democratizing Direct Democracy: Restoring Voter Competence Through Heuristic Cues and "Disclosure Plus," 50 UCLA L. REV. 1141 (2003). 
and meaningless rhetoric in legislative debates. ${ }^{277}$ In addition, the common practice of running for Congress by bashing the institution can only have negative consequences for trust. ${ }^{278}$ Finally, the media tends to magnify the role of the most extreme (and least effective) members of Congress. ${ }^{279}$ The public absorbs what it is being told, but the picture that develops is not one that helps support the institution.

The conclusions reached by Hibbing and Theiss-Morse in their study of the public's preference for "stealth democracy" are more counterintuitive. ${ }^{280}$ They suggest the legislative process should be less transparent, as in less televised and subject to sunshine laws. ${ }^{281}$ Apparently more transparency leads to greater distrust. They argue on the basis of their survey that people prefer rule by the people themselves (direct democracy) or non-self-interested nonelected elites (such as the Supreme Court and Federal Reserve Board) to rule by legislators. ${ }^{282}$ To change the public's overwhelmingly negative opinion of legislators, their contacts with and possible benefits from special interest groups must be reduced to a minimum or eliminated (notwithstanding the First Amendment!). ${ }^{283}$ Hibbing and TheissMorse advance what might be termed an "anti-participation" perspective on democracy: "While people are not eager to provide input into political decisions, they want to know that they could have input into political decisions if they ever wanted to do so. In fact, they are passionate about this." 284

I have largely bypassed the debate between critics and proponents of direct democracy in this Article because I believe both sides are evading a major issue. Direct democracy would not exist had there not been a serious and unanswered problem with representative government. And it could not have persisted or, indeed, grown in strength had there not been background conditions, such as declining trust in government coupled with legislative inaction, that let it flourish. Although critics of direct democracy make occasional gestures toward the flaws of contemporary politics, the depth of genuine popular dissatisfaction with legislatures is rarely acknowledged or

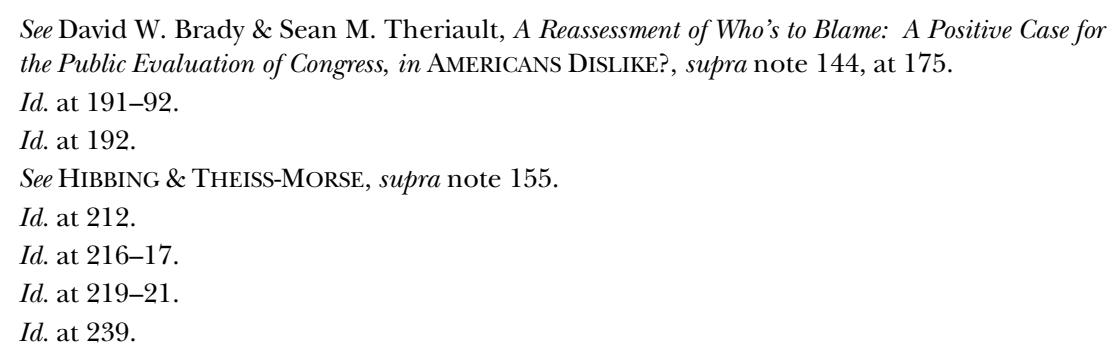


made a subject of sustained analysis. The key problem of trust in government remains largely unexplored in the literature about direct democracy.

There is no road to fundamental reform or abolition of direct democracy without addressing the flaws and equally problematic record of representative government. When we critique direct democracy, we must also acknowledge and critique the flaws of government by legislature. In many ways, they are two aspects of the same problem-the lack of trust in government. This will continue to be a major problem for American constitutionalism. 


\section{APPENDIX}

Illustrative California Ballot Propositions, Approved 1978-98 ${ }^{285}$

\begin{tabular}{|c|c|c|c|}
\hline $\begin{array}{c}\text { PROPOSITION \& } \\
\text { DATE }\end{array}$ & $\begin{array}{l}\text { ICA/ } \\
\text { IS }\end{array}$ & DESCRIPTION & $\begin{array}{l}\text { MARGIN OF } \\
\text { VICTORY }\end{array}$ \\
\hline $\begin{array}{c}\text { Proposition } 13 \\
\text { June } 1978\end{array}$ & ICA & $\begin{array}{l}\text { Property tax reduction and limi- } \\
\text { tation, two-thirds vote for in- } \\
\text { creases }\end{array}$ & $65-35 \%$ \\
\hline $\begin{array}{l}\text { Proposition } 4 \\
\text { Nov. } 1979\end{array}$ & ICA & $\begin{array}{l}\text { Appropriation limits for state and } \\
\text { local government, return of } \\
\text { revenues }\end{array}$ & $74-26 \%$ \\
\hline $\begin{array}{l}\text { Proposition } 62 \\
\text { Nov. } 1986\end{array}$ & ICA & $\begin{array}{l}\text { Regulates new and increased } \\
\text { taxes by local governments }\end{array}$ & $58-42 \%$ \\
\hline $\begin{array}{l}\text { Proposition } 63 \\
\text { Nov. } 1986 \\
\end{array}$ & ICA & English is official state language & $73-27 \%$ \\
\hline $\begin{array}{l}\text { Proposition } 98 \\
\text { Nov. } 1988\end{array}$ & $\begin{array}{l}\text { ICA } \\
\text { IS }\end{array}$ & $\begin{array}{l}\text { Minimum level of funding for } \\
\text { public schools and community } \\
\text { colleges }\end{array}$ & $51-49 \%$ \\
\hline $\begin{array}{l}\text { Proposition } 103 \\
\text { Nov. } 1988\end{array}$ & IS & $\begin{array}{l}\text { Reductions in auto insurance } \\
\text { rates, elected Insurance Commis- } \\
\text { sioner (partly invalidated by state } \\
\text { court) }\end{array}$ & $51-49 \%$ \\
\hline $\begin{array}{l}\text { Proposition } 140 \\
\text { Nov. } 1990 \\
\end{array}$ & ICA & $\begin{array}{l}\text { Term limits for state officials, } \\
\text { limits on salary and expenses }\end{array}$ & $52-48 \%$ \\
\hline $\begin{array}{l}\text { Proposition } 184 \\
\text { Nov. } 1994\end{array}$ & IS & $\begin{array}{l}\text { Sentences for repeat offenders } \\
\text { (“3 strikes”) (identical statute } \\
\text { passed earlier) }\end{array}$ & $72-28 \%$ \\
\hline $\begin{array}{l}\text { Proposition } 187 \\
\text { Nov. } 1994\end{array}$ & IS & $\begin{array}{l}\text { Illegal aliens ineligible for public } \\
\text { social and health services and } \\
\text { education (substantially invali- } \\
\text { dated by federal court) }\end{array}$ & $59-41 \%$ \\
\hline $\begin{array}{l}\text { Proposition } 209 \\
\text { Nov. } 1996\end{array}$ & ICA & $\begin{array}{l}\text { Ends affirmative action in Cali- } \\
\text { fornia }\end{array}$ & $55-45 \%$ \\
\hline $\begin{array}{c}\text { Proposition } 210 \\
\text { Nov. } 1996 \\
\end{array}$ & IS & Increases state minimum wage & $61-39 \%$ \\
\hline $\begin{array}{l}\text { Proposition } 215 \\
\text { Nov. } 1996\end{array}$ & IS & $\begin{array}{l}\text { Use of marijuana for medical } \\
\text { purposes }\end{array}$ & $56-44 \%$ \\
\hline $\begin{array}{l}\text { Proposition } 218 \\
\text { Nov. } 1996\end{array}$ & ICA & $\begin{array}{l}\text { Requires majority voter approval } \\
\text { of local tax and fee increases }\end{array}$ & $57-43 \%$ \\
\hline $\begin{array}{l}\text { Proposition } 227 \\
\text { June } 1998\end{array}$ & IS & Ends bilingual education $^{286}$ & $61-39 \%$ \\
\hline
\end{tabular}

ICA = Initiative Constitutional Amendment; IS = Initiative Statute

286 The legislature passed a more moderate version of this Proposition, but it was vetoed by Governor Pete Wilson. ALLSWANG, supra note 1, at 232. 
